\title{
Impact of Roundup on the marine microbial community, as shown by an in situ microcosm experiment
}

\author{
Sabine Stachowski-Haberkorn ${ }^{a}$, Beatriz Becker ${ }^{b}$, Dominique Marie ${ }^{c}$, Hansy Haberkorn ${ }^{d}$, Louis \\ Coroller $^{\mathrm{a}}$, Denis de la Broise ${ }^{\mathrm{a}, \text { * }}$
}

\footnotetext{
a Université Européenne de Bretagne, LUBEM (EA3882), UBO, 6 rue de l'université, 29334 Quimper, France

${ }^{\mathrm{b}}$ Centre d'Océanologie de Marseille, rue de la Batterie des Lions, 13007 Marseille, France

${ }^{c}$ Station Biologique de Roscoff, UMR7144, CNRS et Université Pierre et Marie Curie, Place G. Teissier, 29682 Roscoff, France

d Université Européenne de Bretagne, LEMAR (UMR 6539), UBO, IUEM, Place Nicolas Copernic, Technopôle Brest Iroise, 29280 Plouzané, France
}

*: Corresponding author : Denis de la Broise, email address : denis.de-labroise@univ-brest.fr

\begin{abstract}
:
The effects of the herbicide Roundup ${ }^{\circledR}$ (glyphosate) on natural marine microbial communities were assessed in a 7-day field experiment using microcosms. Bottles were maintained underwater at $6 \mathrm{~m}$ depth, and $10 \%$ of their water content was changed every other day.

The comparison of control microcosms and surrounding surface water showed that the microcosm system tested here can be considered as representative of the natural surrounding environment. A temporal temperature gradient gel electrophoresis (TTGE) was run on 16S and 18S rDNA-amplified extracts from the whole microbial community. Cluster analysis of the $16 \mathrm{~S}$ gel showed differences between control and treatment fingerprints for Roundup at $1 \mu \mathrm{g} \mathrm{L}^{-1}$ (ANOSIM, $p=0.055 ; R=0.53$ ), and $10 \mu \mathrm{g} \mathrm{L}^{-1}$ (ANOSIM, $p=0.086 ; R=0.40$ ). Flow cytometry analysis revealed a significant increase in the prasinophyte-like population when Roundup concentration was increased to $10 \mu \mathrm{g} \mathrm{L}^{-1}$.

This study demonstrates that a disturbance was caused to the marine microbial community exposed to $1 \mathrm{\mu g} \mathrm{L}^{-1}$ Roundup concentration, a value typical of those reported in coastal waters during a run-off event.
\end{abstract}

Keywords: Microcosm; Marine microbial communities; Glyphosate; TTGE; Flow cytometry 


\section{Introduction}

The massive use of pesticides induces acute or chronic contamination of aquatic biota via spray drift, leaching or runoff from urban and agricultural areas. Herbicides in estuarine areas have been reported at concentrations ranging from several tens to hundreds of ng $\mathrm{L}^{-1}$ (Lehotay et al., 1998; Chesworth et al., 2001; Steen et al., 2001; Oros et al., 2003). These contaminants can negatively impact non-target organisms, including microbial eukaryotes and prokaryotes. In microbial aquatic communities, phytoplankton are potentially vulnerable to herbicides, due to their physiological homologies with terrestrial plants (DeLorenzo et al., 2001; Dorigo et al., 2004). Furthermore, impacts of pesticides on this microbial community could seriously damage the workings of the ecosystem, as the microbial food web plays a critical role in nutrient cycling and transfer of nutrients to higher trophic levels (DeLorenzo et al., 1999a). Numerous studies have been published about pesticide toxicity assessment on phytoplankton, using single-species tests (Sabater and Carrasco, 2001; Rioboo et al., 2002; Sabater et al., 2002; Weiner et al., 2004; Gatidou and Thomaidis, 2007; Santin-Montanya et al., 2007). But 
Bérard et al. (1999) demonstrated that single-species tests may fail to predict indirect or system responses to toxicants, such as changes in population competition or succession. According to these authors, studies focusing on the whole natural community provide more reliable predictions about herbicide safety in aquatic environments.

Toxicity effects on natural communities can be assessed in several ways: by sampling at different natural sites and/or times to look for pollution-related characteristics (Kostanjšek et al., 2005; Pesce et al., 2008); by sampling natural communities from the field and maintaining them in microcosms under controlled laboratory conditions (DeLorenzo et al., 1999b; Seguin et al., 2001); and, finally, by running studies using in situ microcosms. Recently, de la Broise and Palenik (2007) showed that such microcosms immersed in "average water column conditions”, with partial water renewal, can be considered as good experimental models for natural nano- and picophytoplankton from coastal waters. Such in situ micro- or mesocosm experiments provide the best aspects of both laboratory and open field systems, as this experimental set up allows both the testing of multiple replicates and ecological realism (Van den Brink et al., 2002). Microcosms set up in natural environments allow a wider species spectrum to be tested, including populations that are hard to maintain, and can thus provide a wider survey of prokaryote and eukaryote susceptibility to toxicants (Yasuno et al., 1993). Seguin et al. (2001) and Leboulanger et al. (2001) pointed out the need for reliable toxicity data using such microcosm systems.

Genetic fingerprinting techniques, such as Denaturing Gradient Gel Electrophoresis (DGGE) (Muyzer et al., 1993) or Temporal Temperature gradient Gel Electrophoresis (TTGE) (Yoshino et al., 1991) can provide an overview of whole community composition, including unculturable strains, which can account for $90 \%$ of microorganisms (Ward et al., 1990). Both DGGE and TTGE methods have been useful as tools to describe the diversity of the whole prokaryote or eukaryote microbial communities in aquatic environments (Murray et al., 1996; 
Van Hannen et al., 1998; Bernard et al., 2000; Díez et al., 2001; Schäfer et al., 2001; Marie et al., 2006).

More recently, these methods were successfully applied to detect disturbances in microbial communities exposed to pollution (Petersen et al., 2004; Kostanjšek et al., 2005; Pesce et al., 2006, 2008).

Beside genetic fingerprinting techniques, flow cytometry can also provide information about natural microbial community populations, and their abundances (Hofstraat et al., 1994; Jonker et al., 1995; Marie et al., 1999; Rutten et al., 2005). Toxicity assessment using flow cytometry was reported in studies involving either phytoplankton cultures (Cid et al., 1995, 1996; Lage et al., 2001; Stauber et al., 2005; Yu et al., 2007) or natural photosynthetic communities (de la Broise and Palenik, 2007).

Glyphosate is the most commonly used herbicide in the world, for both agricultural and nonagricultural weed control (Woodburn, 2000). The use of this non-selective and broadspectrum herbicide increased dramatically after the introduction of genetically modified glyphosate-resistant crops in 1997 (Giesy et al., 2000). The main formulation of glyphosate is Roundup, where glyphosate is present as an isopropylamine (IPA) salt and its efficiency is enhanced by addition of the surfactant polyoxyethylene amine (POEA) (Tsui and Chu, 2003). As receivers of terrestrial pollution, coastal areas can suffer glyphosate contamination over episodes of several days: for instance, glyphosate was detected over a 11-day period at a peak value of $1.2 \mu \mathrm{g} \mathrm{L}^{-1}$ in the Marennes-Oléron bay (Atlantic coast, France) in late spring 2004 (Burgeot et al., 2007). However, little is known about its impact on natural aquatic microbial communities. To our knowledge only one study has revealed significant disturbance in the sediment bacterial community from a lake, exposed to environmentally relevant glyphosate concentrations (Widenfalk et al., 2008). 
To examine the effects of Roundup on marine microbial communities, the objectives of this study were:

1. To compare microbial communities in microcosms and in surrounding water in order to evaluate the relevance of in situ microcosms.

2. To expose microbial communities to Roundup at environmentally relevant concentrations, in microcosms in situ.

3. To assess the pesticide impacts using flow cytometry and TTGE for analysis of prokaryote and eukaryote natural communities.

\section{Materials and Methods}

In order to assess the effects of Roundup on eukaryote and prokaryote marine microbial communities, a set of microcosms containing natural surrounding filtered seawater was placed in situ and exposed to Roundup. The genetic fingerprints of microcosm communities were obtained from the whole community DNA amplified extracts, using Temporal Temperature Gradient gel Electrophoresis (TTGE) analysis. Chlorophyll a (chl a $)$ measurements were made from biomass collected on filters, and microcosm subsamples were also analysed using flow cytometry, and species determination by microscopy.

\subsection{Pesticide}

The pesticide tested in this study is the commercial formulation of the herbicide glyphosate (Roundup ${ }^{\circledR}$, Monsanto, Saint-Louis, MO, USA). Concentration values represent those of the pure active substance. The pesticide stock solution (10 $\mathrm{mg} \mathrm{L}^{-1}$ glyphosate) was prepared in $0.22 \mu \mathrm{m}$ filtered seawater, previously autoclaved for $20 \mathrm{~min}$ at $121^{\circ} \mathrm{C}$. After agitation for $48 \mathrm{~h}$ using a magnetic stirrer, the solution was kept at $-24{ }^{\circ} \mathrm{C}$. 
Freshly thawed stock solution was added directly into the microcosm bottles just before immersion. Pesticide concentrations were analyzed on the first day of the experiment, on one additional microcosm for each treatment, and on the last day of experiment on pooled water samples from all the replicate bottles of each treatment. Samples were frozen until analysis. Pesticide analyses were performed by Idhesa Laboratory (Brest, France). The determination of glyphosate and its metabolite aminomethylphosphonic acid (AMPA) residues was performed using liquid chromatography with fluorescence detection after liquid-liquid extraction and derivatization with 9-fluorenylmethylchloroformate (FMOC-Cl). Detection limit was $0.05 \mu \mathrm{g} \mathrm{L}^{-1}$.

\subsection{Microcosms}

The outdoor experiment took place in summer 2006, in Port-la-Forêt Bay, south Brittany,

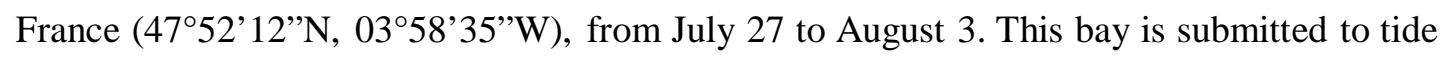
amplitude of 3 to 5 meters, and maximum tidal currents are up to $0.5 \mathrm{~m}$ per second at the experimental site. Light at 6 meter depth was measured twice during the experiment (spherical quantum sensor LI-193 SA from LICOR corporation), and showed an about 10 times intensity reduction as compared to surface light, indicating low turbidity waters. Microcosms consisted of hermetically closed 2.3 L glass bottles. These bottles were filled with $2 \mathrm{~L}$ of $200 \mu \mathrm{m}$ filtered fresh seawater from the surface layer at the field site, containing natural phytoplankton communities, and enclosed with about $300 \mathrm{~mL}$ of air (de la Broise and Palenik, 2007).

Fifteen microcosms were prepared: five replicates each of the three treatments: control and two different concentrations of Roundup $\left(1 \mu \mathrm{g} \mathrm{L} \mathrm{L}^{-1}\right.$ and $\left.10 \mu \mathrm{g} \mathrm{L}^{-1}\right)$. 
Microcosms were hung on a 3 m diameter circular stainless steel frame that was anchored to the sea floor, on a $400 \mathrm{~kg}$ concrete block, and suspended from a surface buoy that allowed the bottles to remain at $6 \mathrm{~m}$ depth, regardless of the tide (Figure 1). The replicate microcosm bottles of each treatment were distributed alternately all around the frame.

On days 2, 4, and 6, the frame was hauled out of the water and $200 \mathrm{~mL}$ of the 2 litre-seawater content of each bottle was collected in a tank for proper disposal, and replaced with the same volume of fresh $200 \mu \mathrm{m}$-filtered surrounding seawater and the frame was re-immersed. No analysis was carried out on these $200 \mathrm{~mL}$-samples. Bottles were finally collected on day 7 for analyses.

On the first and last days of experiment, five samples of surrounding surface seawater (2 L) were also collected for analysis.

One litre of water from each microcosm and one from the surrounding seawater sample were filtered through $0.22 \mu \mathrm{m}$ polysulfone filters. These filters were stored at $-80^{\circ} \mathrm{C}$ until DNA extraction and chl a quantification. For cytometry analyses, samples (1.5 mL) were dropped into cryotubes and fixed with glutaraldehyde (final concentration 0.25\%). Cryotubes were vortexed and left 15 minutes at room temperature before freezing in liquid nitrogen. Samples were stored at $-80^{\circ} \mathrm{C}$ until analysis. For algae species determination, replicate bottles were pooled (200 mL each), and $100 \mathrm{~mL}$ of the pooled samples were fixed using acid Lugol's iodine solution (2\%, final concentration) and kept in the dark.

\subsection{HPLC chl a quantification}

Half of each frozen $0.22 \mu \mathrm{m}$ polysulfone filter was extracted in the dark, in $1 \mathrm{~mL}$ of $95 \%$ methanol as follows: the filter was ground for 3 min using a stainless steel spatula and sonicated on ice for $30 \mathrm{~s}$. The solution was then filtered through a 0.22- $\mu \mathrm{m}$ PVDF syringe filter to remove debris. Aliquots (200 $\mu \mathrm{L}$ ) were injected into the HPLC system (Waters $600 \mathrm{~S}$ 
controller, 616 pump, 600 column heater and 996 diode-array detector). Pigments were separated through a Waters Symmetry-C8 reverse-phase column maintained at $30^{\circ} \mathrm{C}\left(150^{*} 4.6\right.$ mm, $3.5 \mu \mathrm{m}$ particle size, $100 \AA$ pore size). The mobile phase was a gradient mixture of 4 solvents: methanol (100\%), acetonitrile (100\%), acetic acid (100\%) and aqueous pyridine solution (0.25M), as described in Zapata et al. (2000). The eluent gradient program was adapted from Zapata et al. (2000), but whereas Zapata used two eluents prepared from mixed solvents, four single solvents were used in the present study. Chl a concentration, measured at $440 \mathrm{~nm}$, was calibrated against a chl a standard solution (SIGMA, Chlorophyll a from spinach for HPLC Ref 10865).

\subsection{Flow cytometry}

Samples were run using a FACSort flow cytometer equipped with a 488-nm argon laser and standard filter setup (Becton Dickinson, San Jose, CA). Two populations of photosynthetic organisms were discriminated in microcosms samples, on the basis of their scatter signals and their natural red (>630 nm) and orange fluorescence (580 $\pm 20 \mathrm{~nm})$ : Synechococcus and picoeukaryotes $(<10 \mu \mathrm{m})$. Usually, picoplankton is considered to range from $0.2 \mu \mathrm{m}$ to $2 \mu \mathrm{m}$, and nanoplankton from $2 \mu \mathrm{m}$ to $20 \mu \mathrm{m}$. But here, using flow cytometry, the term "picoeukaryotes” is used for cells $<10 \mu \mathrm{m}$.

For more precise analysis, a clear sub-population of small eukaryotes was considered as part of the overall picoeukaryotic distribution (Figure 2). Cells belonging to this sub-population have been identified by flow cytometric sorting in marine samples from different geographic locations, as prasinophytes (D. Marie, unpublished data) and for this reason, we call them prasinophyte-like in the following text. Data were analysed using the WinMDI v2.9 software (J. trotter, http://facs.Scripps.edu/). 


\subsection{Species determination}

Determination and quantification of micro- and nano-phytoplankton cells were carried out at species level as follows: sub-samples of $50 \mathrm{~mL}$ were settled into Utermöhl settling chambers (Hasle, 1978) and counted using a Wild M40 phase contrast inverted microscope. Counts were carried out on partial or whole bottom surface of the chamber, depending on the size and the abundance of the species (Lund et al., 1958), at $\times 200$ to $\times 400$ magnification. When possible, 400 cells were counted to ensure that the error in estimation of cellular abundance remained within the limits of $\pm 10 \%$ (Uehlinger, 1964).

The Shannon-Wiener diversity index H' was calculated using the formula:

$$
H^{\prime}=\Sigma p_{i} \log _{2}\left(p_{i}\right)
$$

were $\mathrm{p}_{\mathrm{i}}$ is the proportion of the total count arising from the $\mathrm{i}^{\text {th }}$ species

\subsection{DNA extraction and purification}

Half of each polysulfone filter $(0.22 \mu \mathrm{m}$ pore size) was cut into small pieces and put in 5-mL polypropylene tubes. Sterile glass beads (0.5 g, 0.1-mm-diameter, SIGMA, Ref G8893) and $500 \mu \mathrm{L}$ of TNE buffer (10 mM Tris-Cl, 100 mM NaCl, 10 mM EDTA, pH 8) were added. Tubes were vortexed for $1 \mathrm{~min}$, in order to disrupt the cells.

Nucleic acid extraction. Lysozyme was added (final concentration, $2 \mathrm{mg} \mathrm{mL}^{-1}$ ) and tubes were then kept at $37^{\circ} \mathrm{C}$ for $45 \mathrm{~min}$. Proteinase $\mathrm{K}$ (final concentration, $0.5 \mathrm{mg} \mathrm{mL}^{-1}$ ) and sodium-dodecyl-sulfate (SDS, final concentration, 1\%) were then added, and tubes incubated at $37^{\circ} \mathrm{C}$ for $30 \mathrm{~min}$. The lysates were purified twice by extraction with an equal volume of phenol-chloroform-isoamyl alcohol (25:24:1), and the residual phenol was removed by two extractions with an equal volume of chloroform-isoamyl alcohol (24:1). Two volumes of isopropanol and sodium acetate (10\% of the total volume, $3 \mathrm{M}, \mathrm{pH} 5.2$ ) were added to the 
aqueous phase. After precipitation (1 h at room temperature), the tubes were centrifuged for $15 \mathrm{~min}$ at $13000 \mathrm{rpm}$. The supernatant was discarded and $1.5 \mathrm{~mL}$ of $70 \%$-ethanol were added. Tubes were centrifuged $10 \mathrm{~min}$ at $13000 \mathrm{rpm}$, and the supernatant discarded. The tubes were then left for a few minutes at room temperature to ensure ethanol evaporation, and nucleic acids were resuspended into $300 \mu \mathrm{L}$ of TE buffer (10 mM Tris-HCl, 1 mM EDTA, pH 8).

RNA digestion. Pre-incubated RNase $\left(10 \mathrm{~min}\right.$ at $80^{\circ} \mathrm{C}$ ) was added (final concentration, $20 \mu \mathrm{g}$ $\mathrm{mL}^{-1}$ ), and tubes were incubated for $30 \mathrm{~min}$ at $37^{\circ} \mathrm{C}$.

DNA purification. This procedure was carried out as for the nucleic acid extraction described above, except in that proteinase $\mathrm{K}$ and SDS final concentrations were $50 \mu \mathrm{g} \mathrm{mL}{ }^{-1}$ and $0.1 \%$, respectively. DNA pellets were suspended in $0.1 \mathrm{x}$ TE buffer.

\subsection{PCR}

Two PCRs were run for each DNA extract.

For the first PCR, eukaryotic 18S ribosomal DNA (rDNA)-universal primers were used. The primers were Euk1A and Euk516r-GC (Díez et al., 2001), which amplify a fragment of approximately 560 bp. The PCR program (Díez et al., 2001) included an initial denaturation step at $94^{\circ} \mathrm{C}$ for $130 \mathrm{~s}$ and 35 cycles as follows: denaturation at $94^{\circ} \mathrm{C}$ for $30 \mathrm{~s}$, annealing at $56^{\circ} \mathrm{C}$ for $45 \mathrm{~s}$ and extension at $72^{\circ} \mathrm{C}$ for $130 \mathrm{~s}$. After the last cycle, a final extension step was performed for $7 \mathrm{~min}$ at $72^{\circ} \mathrm{C}$.

For the second PCR set, prokaryotic 16S rDNA-universal primers were used. The primers were 341F-GC (Muyzer et al., 1993) and 907RC (Schäfer et al., 2001). The PCR program (Massana and Jürgens, 2003) included an initial denaturation step at $94^{\circ} \mathrm{C}$ for $5 \mathrm{~min}$, followed by 10 touchdown cycles including denaturation at $94^{\circ} \mathrm{C}$ for $1 \mathrm{~min}$, annealing for $1 \mathrm{~min}$ (starting at $65^{\circ} \mathrm{C}$ and decreasing by $1^{\circ} \mathrm{C}$ per cycle), and extension at $72^{\circ} \mathrm{C}$ for $3 \mathrm{~min}$. The next 
20 cycles were composed of denaturation at $94^{\circ} \mathrm{C}$ for $1 \mathrm{~min}$, annealing at $55^{\circ} \mathrm{C}$ for $1 \mathrm{~min}$ and extension at $72^{\circ} \mathrm{C}$ for $3 \mathrm{~min}$. A final extension step was performed for $5 \mathrm{~min}$ at $72^{\circ} \mathrm{C}$.

For both PCRs, approximately 15 ng of extracted DNA (estimated using spectrophotometry) were used as a template: the reaction mixture $(50 \mu \mathrm{L})$ contained sterile nuclease-free water, each primer at a final concentration of $0.3 \mu \mathrm{M}$, Bovine Serum Albumin (final concentration $0.2 \mu \mathrm{g} \mu \mathrm{L}^{-1}$ ) and Promega PCR Master Mix, (in which the final concentrations were: deoxynucleoside triphosphates (dNTPs) $200 \mu \mathrm{M}$ each; $\mathrm{MgCl}_{2} 1.5 \mathrm{mM}$; and Taq polymerase 25 units $\mathrm{mL}^{-1}$ ) supplied in a reaction buffer ( $\left.\mathrm{pH} 8.5\right)$.

PCR products were verified on a 1\% agarose gel before loading on TTGE gel.

\subsection{TTGE}

Denaturing gels $(30 \mathrm{~mL})$ were prepared composed of $6 \%$ polyacrylamide (stock solution: acrylamide/bis-acrylamide 37.5:1), $7 \mathrm{M}$ urea, $1.25 \times$ TAE and $2 \%$ glycerol. The stacking gel (5 mL) contained only TAE $1.25 x$ and 6\% polyacrylamide. Ammonium persulfate $10 \%$ (150 and $25 \mu \mathrm{L}$ for the denaturing and the stacking gels respectively) and TEMED (30 and $5 \mu \mathrm{L}$ respectively) were added before casting and the gel was left to polymerize at $20^{\circ} \mathrm{C}$ for $3-4 \mathrm{~h}$. The gel dimensions were $16 \mathrm{~cm} \times 16 \mathrm{~cm} \times 1 \mathrm{~mm}$.

The TTGE was performed by using a Dcode universal mutation system (Bio-Rad), modified to improve accuracy and repeatability of the temperature gradient kinetics: the electrophoresis part of the Dcode system was immersed in a modified buffer tank (15 L). The tank was connected to an external temperature control unit (Cryostat Julabo, Seelbach, Germany) using $20 \mathrm{~mm}$ diameter tubing. Electrophoresis was performed for $18 \mathrm{~h}$ at $70 \mathrm{~V}$ in $1.25 \mathrm{x}$ TAE buffer. Gradual temperature increases were 57 to $62{ }^{\circ} \mathrm{C}$ for $18 \mathrm{~S}$ PCR products, and 63 to $68{ }^{\circ} \mathrm{C}$ for 16S PCR products. Gels were stained with SYBR Gold 1x, rinsed in 1x TAE buffer, and photographed on a UV transillumination table. Band detection on TTGE gel images was 
performed using the LabImage software v2.7 (Kapelan GmbH, Halle, Germany). On the basis of a band presence/absence matrix from each gel, a dendrogram was constructed applying the Dice coefficient and the unweighted pair group method of averages (UPGMA) using the Matlab software v6.1 (The Mathworks, Natik, MA).

For practical reasons, only 4 replicates for control and 3 replicates for each pesticide

treatment were processed for TTGE analysis.

\subsection{Statistical analysis}

The chl a and flow cytometry data were first tested for homogeneity of variances (Bartlett’s test) and normal distributions (Kolmogorov-Smirnov test). As several variables did not fulfill both conditions, a parametric analysis could not be used. Therefore, following the statistical procedures given in Sokal and Rohlf (1995), a Kruskal-Wallis test was used to check for significant differences in multiple treatment sets, and when the answer was positive a MannWhitney test was run for pairwise comparisons. Statistical tests were performed using the Statgraphics ${ }^{\circledR}$ Plus v5.1 software.

In order to test for significant differences between the genetic fingerprints obtained from different treatments, analyses of similarity (Clarke, 1993) were performed on binary matrixes using the one-way ANOSIM function in the Past v1.77 software (Hammer et al., 2001).

\section{Results}




\subsection{Comparison between Control and Surrounding water}

The chl a concentration in the surrounding water (Figure 3) ranged from $0.93 \pm 0.07 \mu \mathrm{g} \mathrm{L}{ }^{-1}$ (mean \pm SE) on day 0 to $1.71 \pm 0.097 \mu g \mathrm{~L}^{-1}$ on day 7 , showing almost a 2-fold increase. In controls on day 7 , the chl a concentration had increased up to $1.31 \pm 0.16 \mu \mathrm{g} \mathrm{L}^{-1}$, but this was not significantly lower than the level in surrounding water on the same day $(\mathrm{p}=0.11)$.

Similarly, the total cellular concentration obtained using flow cytometry analysis (Figure 4)

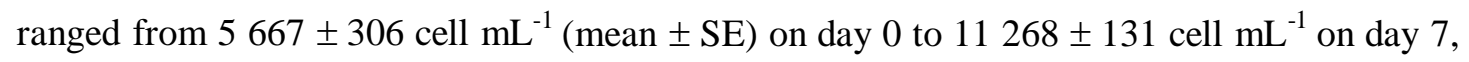
showing a 2-fold increase. The value obtained for control microcosms on day 7 (9 $943 \pm 480$ cell $\mathrm{mL}^{-1}$ ) was not significantly different from that of surrounding seawater on the same day. The Synechococcus cellular concentration in the surrounding water (Figure 4) did not increase significantly between day 0 and day 7 (3 $152 \pm 180$ and $3467 \pm 138$ cell mL ${ }^{-1}$, respectively). This population was significantly lower in the control microcosms on day 7 (1 $454 \pm 131$ cell $\mathrm{mL}^{-1}$, Mann-Whitney, $\mathrm{p}<0.05$ ) compared to the surrounding water.

The total pico-eukaryote cellular concentration in the surrounding water (Figure 4) increased from $2515 \pm 164$ cell $\mathrm{mL}^{-1}$ on day 0 , to $7801 \pm 200$ cell mL $^{-1}$ on day 7 and values were not significantly different between control microcosms (8 $489 \pm 562$ cell mL ${ }^{-1}$ ) and surrounding water on day $7(\mathrm{p}=0.27)$.

On the first day of experiment, 31 species were identified using microscopy in the algal community of the surrounding water. On the last day of experiment, 30 were found. A similar value (32 species) was observed in the control on the last day. The Shannon-Wiener diversity indexes $\left(\mathrm{H}^{\prime}\right)$ were also close in surrounding water on the first and last days, and in control microcosms on the last day (Table 1).

Nine main groups composed the surrounding water and control communities on the first and last days of experiment (Figure 5). Relative abundance of diatoms increased from $31 \%$ in the 
surrounding water on the first day to $84 \%$ on the last day, while it accounted for $63 \%$ in the control. The diatom group was mostly represented by the genus Chaetoceros (25\% of the total abundance on the first day, 53\% on the last day, and 50\% in the control), and the species Leptocylindrus danicus (2.5\% of the total abundance on the first day, $21 \%$ on the last day, and $10 \%$ in the control). Dinoflagellate relative abundances were no higher than $12 \%$ in the surrounding water on the first day ( $11 \%$ Gymnodinium spp.), but they dropped to $0.8 \%$ by the last day, and accounted for $1.2 \%$ in the control. The most abundant group, undetermined flagellates, represented $57 \%$ of the total abundance in surrounding water on the first day, $15 \%$ on the last day and 36\% in the control.

From these data, it appears that the abundances of these 4 main groups observed in the control match the range of abundances observed in the surrounding water between the first and the last day of the experiment.

\subsection{Microbial community exposure to Roundup}

\subsubsection{Pesticide exposure}

The control microcosms and the surrounding seawater did not contain detectable glyphosate during the experiment (Table 2). The concentrations detected for Roundup-treated microcosms on the first day of experiment ranged from $11 \%$ of the nominal amount added for the $1 \mu \mathrm{g} \mathrm{L}^{-1}$ treatment, to $36 \%$ for the $10 \mu \mathrm{g} \mathrm{L}^{-1}$ treatment. At the end of the experiment, levels ranged from $13 \%$ to $31 \%$ for the $1 \mu \mathrm{g} \mathrm{L}{ }^{-1}$ and $10 \mu \mathrm{g} \mathrm{L}{ }^{-1}$ treatments respectively. The metabolite AMPA was not detected in any of the samples. 


\subsubsection{Chlorophyll $\underline{a}$ in microcosms}

The chl a concentration (1.31 $\pm 0.16 \mu \mathrm{g} \mathrm{L}^{-1}$ in control microcosms, Figure 6) was not affected by the Roundup exposure, either at 1 or $10 \mu \mathrm{g} \mathrm{L}^{-1}$ (Mann-Whitney, $\mathrm{p}=0.99$ and 0.71 , respectively).

\subsubsection{Roundup effects on prokaryote communities}

Image analysis of the TTGE gel from the16S PCR products (Figure 7a) allowed the detection of 12 to 16 major bands for the control microcosms, 14 to 17 for microcosms treated with 1

$\mu \mathrm{g} \mathrm{L}{ }^{-1}$ of Roundup, and 10 to 16 for the $10 \mu \mathrm{g} \mathrm{L}^{-1}$ exposure. A total of 23 different bands were detected on the whole gel.

The dendrogram generated from this banding pattern (Figure 7b) exhibited a clear separation of the control microcosms on the one hand, and the herbicide-treated microcosms on the other. Only one sample fingerprint (a $10 \mu \mathrm{g} \mathrm{L}^{-1}$ Roundup replicate) was situated outside of these two clusters. The ANOSIM from the cluster analysis between the control group and the Roundup treatments showed p-values of 0.055 and 0.086 for the Roundup at $1 \mu \mathrm{g} \mathrm{L}^{-1}$ and 10 $\mu \mathrm{g} \mathrm{L}{ }^{-1}$, respectively. The $\mathrm{R}$ values obtained were 0.53 for Roundup $1 \mu \mathrm{g} \mathrm{L}{ }^{-1}$ and 0.40 for Roundup $10 \mu \mathrm{g} \mathrm{L}^{-1}$. There was no evidence of a difference in the effect of 1 and $10 \mu \mathrm{g} \mathrm{L}^{-1}$ treatments on these communities, as fingerprints from both treatments were grouped together. When the control group was tested against both treatments together, a p-value of $0.021(\mathrm{R}=$ 0.44) was observed.

The prokaryotic $\underline{\text { Synechococcus }}$ counts in microcosms, obtained from flow cytometry analysis (Figure 8) did not show significant differences between the controls and either Roundup treatment. Roundup does not show any significant effect on Synechococcus relative fluorescence values (data not shown). 


\subsubsection{Roundup effects on eukaryote communities}

Image analysis of the TTGE gel from the 18S PCR products (Figure 9a) allowed the detection of 9 to 14 major bands for the control microcosms, 7 to 12 for microcosms treated with $1 \mu \mathrm{g}$

$\mathrm{L}^{-1}$ of Roundup, and 13 to 17 for the $10 \mu \mathrm{g} \mathrm{L} \mathrm{L}^{-1}$ exposure. A total of 22 different bands were detected on the whole gel.

The cluster analysis (Figure 9b) revealed no clear separation of the patterns, even for the highest pesticide concentration, and the ANOSIM results did not indicate significant differences ( $\mathrm{p}>0.10$, data not shown).

Flow cytometry analysis revealed no significant difference in total pico-eukaryote counts (Figure 8) or fluorescence (data not shown) between the control microcosms (8 $489 \pm 562$ cell $\mathrm{mL}^{-1}$, mean $\pm \mathrm{SE}$ ) and either $1 \mu \mathrm{g} \mathrm{L} \mathrm{L}^{-1}\left(7638 \pm 522\right.$ cell mL $\left.^{-1}\right)$ or $10 \mu \mathrm{g} \mathrm{L}^{-1}(8675 \pm 635$ cell $\mathrm{mL}^{-1}$ ) Roundup treatment.

However, though the prasinophyte-like cell count was not significantly enhanced (MannWhitney, $\mathrm{p}=0.06$ ) for the $1 \mu \mathrm{g} \mathrm{L}^{-1}$ treatment, it was significantly higher at $10 \mu \mathrm{g} \mathrm{L}^{-1}$ Roundup, with a cellular concentration increase of $43 \%$ (Figure 10).

The microscopic observation of samples allowed the identification of 32 species for the control, but only 24 and 26 for the Roundup treatments at 1 and $10 \mu \mathrm{g} \mathrm{L}^{-1}$, respectively. The associated Shannon-Wiener diversity indexes also dropped in treatments compared with the control (Table 1). Although a statistical treatment cannot be applied to such data, the quantification of the main groups (Figure 11) suggests, in treated microcosms during the experiment, a higher decrease of Leptocylindrus danicus and a lower increase of Chaetoceros sp. cells than in control microcosms and in surrounding waters (Figure 5). Undetermined flagellates were maintained at values much higher in treated microcosms than in control or in surrounding waters. 


\section{Discussion}

\subsection{Are microcosm contents representative of the mixed layer?}

For practical reasons, seawater for renewal was collected in the $50 \mathrm{~cm}$ surface layer. The mixed layer of ocean surface waters is estimated to fluctuate from several meters depth in very calm conditions, to 100 meters or more in strong wind and wave conditions (Bendtsen et al, 2006; Nilsen and Falck, 2006). Therefore, at the beginning of experiment, the water content of such microcosms can be considered as representative of coastal surface waters. The in situ microcosms used in the present study were exposed to natural underwater temperature and light conditions. Following previous experiments, it was decided to renew $10 \%$ of the bottle content every other day in order to mimic the evolution of the surrounding water, and an air overlay was also included to simulate gas exchanges occurring in free seawater (de la Broise and Palenik, 2007).

The chl a measurements in controls on day 7 exhibited values that were not significantly different from the surrounding water on the same day. Total abundances and picoeukaryotes were greatly enhanced during the experiment, both in surrounding water and in controls. Only $27 \%$ of the microcosm water content was changed overall during this period, however, control and surrounding water values were quite close on day 7. Only Synechococcus counts were clearly lower in controls on day 7, compared with surrounding seawater. However, this cyanobacterium is known to fluctuate rapidly over a wide range in coastal waters. Li et al (2006) reported daily variations of Synechococcus biomass in the Yellow Sea, ranging from 2 to $8 \mathrm{mg} \mathrm{C} \mathrm{m}^{-3}$. Uysal and Köksalan (2006) reported a 4-fold increase of Synechococcus counts over a 6 day period in a survey on eastern Mediterranean Sea coastal waters. The authors found that the observed fluctuations were characteristic of shallow coastal waters, 
with rapidly changing environmental conditions. Therefore, based on its reported natural variations, the present result showing a Synechococcus concentration reduced by half in controls compared with surrounding water does not seem surprising.

The number of species and diversity index showed similar values for control and surrounding water at the end of experiment. Furthermore, the 3 major groups identified were also the same.

These data suggest that the environmental conditions that drive short-term fluctuations were realistic enough in microcosms for the maintenance of a phytoplankton community representative of natural water in the area.

\subsection{Pesticide exposure}

As medium renewal was $10 \%$ every other day, the pesticide loss in microcosms after seven days should be approximately $27 \%$ of the nominal amount added. Data from glyphosate analyses on the first and last days of experiment showed concentrations much lower than those expected. This could be due to an underestimation of the glyphosate present in the samples, or to its possible adsorption to the bottle walls and/or on the organic matter or multivalent cations present in seawater. Indeed, Freuze et al. (2007) demonstrated that the FMOC method applied in this study, could underestimate both glyphosate and AMPA in the presence of multivalent cations. They also showed that only free forms of AMPA and glyphosate were able to react with the FMOC reagent. Overall, the authors indicate that the efficiency of the method depends on the water sample type and content (cations, organic matter etc.).

No detectable concentrations of AMPA were observed in treatments on day 7. This could be explained by AMPA concentrations below the detection limit; by the same adsorption 
mechanism described for glyphosate; or due to low glyphosate degradation kinetics, under such conditions.

To our knowledge, very few reports on glyphosate concentrations in coastal waters are available. This lack of data may be linked to the high polarity of the molecule, close in structure to many naturally occurring amino acids, that makes its detection difficult in water samples (Skark et al., 1998; Rubio et al., 2003). This difficulty is probably worsened by the low concentrations occurring in coastal waters. A peak value of $1.2 \mu \mathrm{g} \mathrm{L}{ }^{-1}$ over a 11-day period was detected in the Marennes-Oléron bay (salinity 33 \%) (Atlantic coast, France) in late spring 2004 (Burgeot et al., 2007). Analyses performed by Idhesa Laboratory (Brest, France) reported maximal concentrations in the Bay of Brest (2002 to 2004), of $0.41 \mu \mathrm{g} \mathrm{L}^{-1}$ for glyphosate, and $0.64 \mu \mathrm{g} \mathrm{L}{ }^{-1}$ for AMPA, in salinity 27 \%o or higher (Gaël Durand, personnal communication). While the highest concentration tested in the present experiment (10 $\mu \mathrm{g} \mathrm{L}^{-1}$ added, $3.6 \mu \mathrm{g} \mathrm{L}^{-1}$ detected on day 0 ) can be found in rivers or may represent an outstanding pollution peak in estuarine areas, the lowest concentration tested $\left(1 \mu \mathrm{g} \mathrm{L}^{-1}\right.$ added, $0.11 \mu \mathrm{g} \mathrm{L}^{-1}$ detected on day 0 ) is representative of coastal pollution.

\subsection{Roundup impact on prokaryote communities}

Comparison of TTGE fingerprints from control and Roundup-treated communities revealed significant differences ( $p$-values in the range $0.05-0.1$ ). The $R$ values were 0.53 and 0.40 , for

Roundup 1 and $10 \mu \mathrm{g} \mathrm{L}^{-1}$ respectively, indicating that the two treated groups separate from the control group in the high dimensional space defined by the similarity matrix (Clarke, 1993). The p-value was reduced to 0.021 when both treatments were tested together against the control. This increased discrimination when treatments were grouped is probably due to the fact that such a non-parametric analysis is not very powerful, especially with small samples. These results clearly show a change in the prokaryote community composition, even with 1 
$\mu g \mathrm{~L}^{-1}\left(0.11 \mu \mathrm{g} \mathrm{L}^{-1}\right.$ detected on day 0$)$. Other studies have been reported that used TTGE from 16S PCR products to monitor pesticide toxicity on natural riverine microbial communities, using either pooled DNA extracts from replicates before PCR (Pesce et al., 2006), or no replication (Pesce et al., 2008). In our study, three or four replicates per treatment were extracted, amplified and separated. This allowed the statistical tool ANOSIM to be applied to test for significant differences between groups of fingerprints. As far as we know this is the first time that the ANOSIM has been applied to an ecotoxicologic study using TTGE gel cluster analysis, and its relevance was clearly illustrated.

In spite of this significant difference observed in Roundup treatments compared to controls, no difference was observed in the number of bands detected: the prokaryote diversity might have been disturbed qualitatively, rather than quantitatively. The changes in the TTGE patterns cannot be precisely interpreted, since no sequencing of discriminating bands or other measurement on the bacterial compartment were done. Flow cytometry data shows that $\underline{\text { Synechococcus, }}$ was apparently not affected by Roundup. As $\underline{\text { Synechococcus }}$ is the major autotrophic prokaryote in mesotrophic and coastal areas (Olson et al., 1988; Partensky et al., 1996), we can then hypothesize that the impacted organisms were either heterotrophic prokaryotes or other minor autotrophs that could not be discriminated using flow cytometry. Various hypothesis could explain this result: the Roundup could affect some prokaryote populations and thus allow the increase of their competitors, or some populations could even be stimulated (El Fantroussi et al., 1999). The changes could also indicate modified grazing pressure due to the possible pesticide impact on heterotrophic eukaryotes. TTGE changes could even indicate modified nutrient sources for prokaryotes, due to Roundup disturbance on other organisms of the microbial loop. Working on bacterial community composition of Lake Erken (Sweden) sediments, Widenfalk et al. (2008) recently reported significant changes in 
microbial communities of sediments exposed to $150 \mu \mathrm{g} \mathrm{kg}^{-1}$ (dry weight) of glyphosate, using the terminal restriction fragment length polymorphism (T-RFLP) analysis. Unfortunately, such data are scarce in the literature, and should be complemented with further studies.

\subsection{Roundup impact on eukaryote communities}

The whole eukaryote community, including autotroph and heterotroph planktonic cells, as well as grazers $(<200 \mu \mathrm{m})$, was targeted in the18S-TTGE analytical procedure. The cluster analysis of the $18 \mathrm{~S}$ community fingerprints did not indicate any impact of Roundup on eukaryotes. However, the trophic diversity of organisms targeted, together with the possible bias introduced by the heterogeneity of 18S rRNA gene and its amplification (preferential amplification of some sequences, gene copy number per cell, Van Hannen et al., 1998), can complicate the detection of potential effects. Based on these aspects, we can hypothesize that a slight effect on a reduced number of eukaryotic components would probably not be detected using this method. Flow cytometry analyses revealed a significant increase in the cellular concentration of the prasinophyte-like population. This indicates that these organisms had been stimulated, which may have occurred directly, or indirectly by an effect on a potential competitor. This effect could also be explained by a possible impact on grazers, inducing a modified grazing pressure, or changes in nutrient sources. It should be noted that the p-value

of the test for prasinophyte-like concentration at $1 \mu \mathrm{g} \mathrm{L} \mathrm{L}^{-1}$ of Roundup was 0.06 . This suggests that the effect of Roundup on prasinophyte-like concentration starts as low as $1 \mu \mathrm{g} \mathrm{L}^{-1}$. In this case flow cytometry analyses seem more sensitive than TTGE for detecting the impact of Roundup on the eukaryote community.

Flow cytometry analyses are run on approximately 250-300 $\mu \mathrm{L}$ of sample and the diameter of the flow cell is below $80 \mu \mathrm{m}$. So only small cells $(<10 \mu \mathrm{m})$ at relatively high concentrations can be discriminated, which usually correspond to the smallest part of the nanophytoplankton 
(2-20 $\mu \mathrm{m})$ and picophytoplankton $(0.2-2 \mu \mathrm{m})$. The larger nanophytoplankton cells, and the microphytoplankton cells $(20-200 \mu \mathrm{m})$ are not detected using flow cytometry because of their size and/or their low concentration in natural samples. This is the reason why qualitative and quantitative analyses of species, using microscopy, are required: they provide additional information and give a wider view of the eukaryote communities.

For practical reasons, the microscopic determination of species was run only on one pooled sample for each condition, and therefore no statistical treatments could be applied. However, data suggest that less species might be present in the treated microcosms compared with the control, and that the distribution of some species could be modified.

\section{Conclusion}

In situ microcosms were demonstrated to be a realistic model for toxicity studies on coastal waters. Our results show that the herbicide Roundup can affect natural coastal microbial communities after a 7-day exposure at $1 \mu \mathrm{g} \mathrm{L} \mathrm{L}^{-1}\left(0.13 \mu \mathrm{g} \mathrm{L}{ }^{-1}\right.$ detected) for prokaryotes and at $10 \mu \mathrm{g} \mathrm{L}^{-1}$ (3.1 $\mu \mathrm{g} \mathrm{L}^{-1}$ detected) for some pico-eukaryotes. This effect was detected for glyphosate concentrations typical of those already observed in polluted coastal areas. It leads us to conclude that glyphosate pollution during runoff events can modify microbial communities in some coastal areas. Effects could be attributed to impacts on competitors for nutrients, leading to community reorganisation and to colonization of empty ecological niches. But these effects could also be attributed to changes in nutrient sources or to modified grazing pressure by the heterotrophic eukaryotes. This study provides information about the high sensitivity of planktonic microorganisms to glyphosate exposure in environmentally relevant conditions. As AMPA is also found in coastal waters, its impact on microbial communities along with the impact of other pesticides should also be assessed. 
Further experiments would be needed in order to identify the organisms impacted and their contribution to the global equilibrium of the microbial system. It will also be necessary to clarify whether such effects could occur during other periods of the year.

\section{Acknowledgements}

We wish to thank the “Ministère de l’Ecologie et du Développement Durable”, and the "Région Bretagne”, who financially supported this research. We also thank the "Capitainerie de Beg-Meil”, city of Fouesnant and Patrick Le Coz for their technical assistance, Geneviève Arzul, James Devillers, Gaël Durand, Marcel Koken, Gwendolina Limon, Nicolas Chomérat and Louis Quiniou. We are especially grateful to Bob Clarke for his precious advice about ANOSIM.

\section{References}

Bendtsen, J., Gustafsson, K.E, Petersen, J.K., 2006. Modelling vertical mixing in the surface boundary layer using artificial age tracers. J. Mar. Syst. 60, 115-128.

Bérard, A., Leboulanger, C., Pelte, T., 1999. Tolerance of Oscillatoria limnetica Lemmermann to Atrazine in Natural Phytoplankton Populations and in Pure Culture: Influence of Season and Temperature. Arch. Environ. Contam. Toxicol. 37, 472-479.

Bernard, L., Schäfer, H., Joux, F., Courties, C., Muyzer, G., Lebaron, P., 2000. Genetic diversity of total, active and culturable marine bacteria in coastal seawater. Aquat. Microb. Ecol. 23, 1-11.

Burgeot, T., Gagnaire, B., Renault, T., Haure, J., Moraga, D., David, E., Boutet, I.., Sauriau, P.G., Malet, N., Bouchet, V., Le Roux, A., Lapègue, S., Bouilly, K., Le Moullac, G., Arzul, G., Knoery, J., Quiniou, F., Bacher, C., Soletchnik, P., 2007. Summer mortality 
of Pacific oyster Crassostrea gigas. The Morest Project. Samain J.F. and McCombie H. (eds). Ed. Ifremer/Quæ, Versailles, France, pp. 107-151.

Chesworth, J. C., Donkin, M. E., Brown, M.T., 2004. The interactive effects of the antifouling herbicides Irgarol 1051 and Diuron on the seagrass Zostera marina (L.). Aquat. Toxicol. 66, 293-305.

Cid, A., Herrero, C., Torres, E., Abalde, J., 1995. Copper toxicity on the marine microalgae Phaeodactylum tricornutum: effects on photosynthesis and related parameters. Aquat. Toxicol. 31, 165-174.

Cid, A., Fidalgo, P., Herrero, C., Abalde, J., 1996. Toxic action of copper on the membrane system of a marine diatom measured by flow cytometry. Cytometry 25, 32-36.

Clarke, K. R., 1993. Non-parametric multivariate analyses of changes in community structure. Austral Ecol. 18, 117-143.

de la Broise, D., Palenik, B., 2007. Immersed in situ microcosms: A tool for the assessment of pollution impact on phytoplankton. J. Exp. Mar. Biol. Ecol. 341, 274-281.

DeLorenzo, M.E., Lauth, J., Pennington, P.L., Scott, G.I., Ross, P.E., 1999a. Atrazine effects on the microbial food web in tidal creek mesocosms. Aquat. Toxicol. 46, 241-251.

DeLorenzo, M.E., Scott, G.I., Ross, P.E., 1999b. Effects of the agricultural pesticides atrazine, deethylatrazine, endosulfan, and chlorpyrifos on an estuarine microbial food web. Environ. Toxicol. Chem. 18, 2824-2835.

DeLorenzo, M.E., Scott, G.I., Ross, P.E., 2001. Toxicity of pesticides to aquatic microorganisms: a review. Environ. Toxicol. Chem. 20, 84-98.

Diez, B., Pedros-Alio, C., Marsh, T.L., Massana, R., 2001. Application of Denaturing Gradient Gel Electrophoresis (DGGE) To Study the Diversity of Marine Picoeukaryotic Assemblages and Comparison of DGGE with Other Molecular Techniques. Appl. Environ. Microbiol. 67, 2942-2951. 
Dorigo, U., Bourrain, X., Bérard, A., Leboulanger, C., 2004. Seasonal changes in the sensitivity of river microalgae to atrazine and isoproturon along a contamination gradient. Sci. Total Environ. 318, 101-114.

el Fantroussi, S., Verschuere, L., Verstraete, W., Top, E.M., 1999. Effect of Phenylurea Herbicides on Soil Microbial Communities Estimated by Analysis of 16S rRNA Gene Fingerprints and Community-Level Physiological Profiles. Appl. Environ. Microbiol. 65, 982-988.

Freuze, I., Jadas-Hecart, A., Royer, A., Communal, P.Y., 2007. Influence of complexation phenomena with multivalent cations on the analysis of glyphosate and aminomethyl phosphonic acid in water. J. Chromatogr. A 1175, 197-206.

Gatidou, G., Thomaidis, N.S., 2007. Evaluation of single and joint toxic effects of two antifouling biocides, their main metabolites and copper using phytoplankton bioassays. Aquat. Toxicol. 85, 184-191.

Giesy, J.P., Dobson, S., Solomon, K.R., 2000. Ecotoxicological risk assessment for Roundup herbicide. Rev. Environ. Contam. T. 167, 35-120.

Hammer, Ø., Harper, D.A.T., Ryan, P. D., 2001. PAST: Paleontological Statistics Software Package for Education and Data Analysis. Palaeontologia Electronica 4(1): 9pp. http://palaeo-electronica.org/2001_1/past/issue1_01.htm

Hasle, G.R., 1978. The inverted microscope method. In: Sournia, A. (Ed.), Phytoplankton manual. UNESCO, Paris, pp 88-96.

Hofstraat, J.W., van Zeijl, W.J.M., de Vreeze, M.E.J., Peeters, J.C.H., Peperzak, L., Colijn, F., Rademaker, T.W.M., 1994. Phytoplankton monitoring by flow cytometry. J. Plankton Res. 16, 1197-1224.

Jonker, R.R., Meulemans, J.T., Dubelaar, G.B.J., Wilkins, M.F., Ringelberg, J., 1995. Flow cytometry: a powerful tool in analysis of biomass distributions in phytoplankton. 
Water Sci. Technol. 32, 177-182.

Kostanjsek, R., Lapanje, A., Drobne, D., Nikcevic, S., Perovic, A., Zidar, P., Štrus, J., Hollert, H., Karaman, G., 2005. Bacterial Community Structure Analyses to Assess Pollution of Water and Sediments in the Lake Shkodra/Skadar, Balkan Peninsula. Environ. Sci. \& Pollut. Res. 12, 361-368.

Lage, O.M., Sansonetty, F., O’Connor, J.E., Parente, A.M., 2001. Flow cytometric analysis of chronic and acute toxicity of copper(II) on the marine dinoflagellate Amphidinium carterae. Cytometry 44, 226-235.

Leboulanger, C., Rimet, F., Hème de Lacotte, M., Bérard, A., 2001. Effects of atrazine and nicosulfuron on freshwater microalgae. Environ. Int. 26, 131-135.

Lehotay, S.J., Harman-Fetcho, J.A., McConnell, L.L., 1998. Agricultural pesticide residues in oysters and water from two Chesapeake bay tributaries. Mar. Pollut. Bull. 37, 32-44.

Li, H., Xiao, T., Ding, T., Lu, R., 2006. Effect of the Yellow Sea Cold Water Mass (YSCWM) on distribution of bacterioplankton. Acta Ecologica Sinica 26, 1012-1019.

Lund, J.W.G., Kipling, C., Le Cren, E.D., 1958. The inverted microscope method of estimating algal numbers and the statistical basis of estimations by counting. Hydrobiologia 11, 143-170.

Marie D., Brussaard C., Partensky F. and Vaulot D. Flow cytometric analysis of phytoplankton, bacteria and viruses. 1999. In: Current Protocols in Cytometry. John Wiley \& Sons, Inc. 11.11.1-11.11.15.

Marie, D., Zhu, F., Balagué, V., Ras, J., Vaulot, D., 2006. Eukaryotic picoplankton communities of the Mediterranean Sea in summer assessed by molecular approaches (DGGE, TGGE, QPCR). FEMS Microbiol. Ecol. 55, 403-415.

Massana, R., Jürgens, K., 2003. Composition and population dynamics of planktonic bacteria and bacterivorous flagellates in seawater chemostat cultures. Aquat. Microb. Ecol. 32, 
$11-22$.

Murray, A.E., Hollibaugh, J.T., Orrego, C., 1996. Phylogenetic compositions of bacterioplankton from two California estuaries compared by denaturing gradient gel electrophoresis of 16S rDNA fragments. Appl. Environ. Microbiol. 62, 2676-2680.

Muyzer, G., de Waal, E.C., Uitterlinden, A.G., 1993. Profiling of complex microbial populations by denaturing gradient gel electrophoresis analysis of polymerase chain reaction-amplified genes coding for 16S rRNA. Appl. Environ. Microbiol. 59, 695700.

Nilsen, J.E.O., Falck, E., 2006. Variations of mixed layer properties in the Norwegian sea for the period 1948-1999. Prog. Oceanogr. 70, 58-90

Olson, R.J., Chisholm, S.W., Zettler, E.R., Armbrust, E.V., 1988. Analysis of Synechococcus pigment types in the sea using single and dual beam flow cytometry. Deep Sea Research 35, 425-440.

Oros, D.R., Jarman, W.M., Lowe, T., David, N., Lowe, S., Davis, J.A., 2003. Surveillance for previously unmonitored organic contaminants in the San Francisco estuary. Mar. Pollut. Bull. 46, 1102-1110.

Partensky, F., Blanchot, J., Lantoine, F., Neveux, J., Marie, D., 1996. Vertical structure of picophytoplankton at different trophic sites of the tropical northeastern Atlantic Ocean. Deep Sea Research 43, 1191-1213.

Pesce, S., Fajon, C., Bardot, C., Bonnemoy, F., Portelli, C., Bohatier, J., 2006. Effects of the phenylurea herbicide diuron on natural riverine microbial communities in an experimental study. Aquat. Toxicol. 78, 303-314.

Pesce, S., Fajon, C., Bardot, C., Bonnemoy, F., Portelli, C., Bohatier, J., 2008. Longitudinal changes in microbial planktonic communities of a French river in relation to pesticide and nutrient inputs. Aquat. Toxicol. 86, 352-360. 
Petersen, D.G., Dahllof, I., Nielsen, L.P., 2004. Effects of zinc pyrithione and copper pyrithione on microbial community function and structure in sediments. Environ. Toxicol. Chem. 23, 921-928.

Rioboo, C., Gonzalez, O., Herrero, C., Cid, A., 2002. Physiological response of freshwater microalga (hlorella vulgaris) to triazine and phenylurea herbicides. Aquat. Toxicol. 59, 225-235.

Rubio, F., Veldhuis, L.J., Clegg, B.S., Fleeker, J.R., Hall, J.C., 2003. Comparison of a Direct ELISA and an HPLC Method for Glyphosate Determinations in Water. J. Agric. Food Chem. 51, 691-696.

Rutten, T.P.A., Sandee, B., Hofman, A.R.T., 2005. Phytoplankton monitoring by high performance flow cytometry: A successful approach? Cytom. Part A 64A, 16-26.

Sabater, C., Carrasco, J.M., 2001. Effects of pyridaphenthion on growth of five freshwater species of phytoplankton. A laboratory study. Chemosphere 44, 1775-1781.

Sabater, C., Cuesta, A., Carrasco, R., 2002. Effects of bensulfuron-methyl and cinosulfuron on growth of four freshwater species of phytoplankton. Chemosphere 46, 953-960.

Santin-Montanya, I., Sandin-Espana, P., Garcia Baudin, J.M., Coll-Morales, J., 2007. Optimal growth of Dunaliella primolecta in axenic conditions to assay herbicides. Chemosphere 66, 1315-1322.

Schäfer, H., Bernard, L., Courties, C., Lebaron, P., Servais, P., Pukall, R., Stackebrandt, E., Trousselier, M., Guindulain, T., Vives-Rego, J., Muyzer, G., 2001. Microbial community dynamics in Mediterranean nutrient-enriched seawater mesocosms: changes in the genetic diversity of bacterial populations. FEMS Microbiol. Ecol. 34, 243-253.

Seguin, F., Leboulanger, C., Rimet, F., Druart, J.C., Bérard, A., 2001. Effects of atrazine and nicosulfuron on phytoplankton in systems of increasing complexity. Arch. Environ. 
Contam. Toxicol. 40, 198-208.

Skark, C., Zullei-Seibert, N., Schottler, U., Schlett, C., 1998. The Occurrence of Glyphosate in Surface Water. Int. J. Environ. Anal. Chem. 70, 93-104.

Sokal R.R., Rohlf, F.J., 1995. Biometry: the principles and practice of statistics in biological research. 3rd edition. W. H. Freeman and Co., New York.

Stauber, J., Adams, M., 2005. Microalgal toxicity tests using flow cytometry. Small-Scale Freshwater Toxicity Investigations 1, 203-241.

Steen, R.J.C.A., van der Vart, J., Hiep, M., Van Hattum, B., Cofino, W.P., Brinkman, U.A.T., 2001. Gross fluxes and estuarine behaviour of pesticides in the Scheldt Estuary (19951997) Environ. Pollut.115, 65-79.

Tsui, M.T.K., Chu, L.M., 2003. Aquatic toxicity of glyphosate-based formulations: comparison between different organisms and the effects of environmental factors. Chemosphere 52, 1189-1197.

Uehlinger, V., 1964. Etude statistique des méthodes de dénombrement planctonique. Arch. Sci. 17, 11-223.

Uysal, Z., Koksalan, I., 2006. The annual cycle of Synechococcus (cyanobacteria) in the northern Levantine Basin shelf waters (Eastern Mediterranean). Marine Ecology 27, 187-197.

Van den Brink, P.J., Hartgers, E.M., Gylstra, R., Bransen, F., Brock, T.C.M., 2002. Effects of a Mixture of Two Insecticides in Freshwater Microcosms: II. Responses of Plankton and Ecological Risk Assessment. Ecotoxicology 11, 181-197.

Van Hannen, E.J., Van Agterveld, M P., Gons, H.J., Laanbroek, H.J., 1998. Revealing genetic diversity of eukaryotic microorganisms in aquatic environments by denaturing gradient gel electrophoresis. J. Phycol. 34, 206-213.

Ward, D.M., Weller, R., Bateson, M.M., 1990. 16 S rRNA sequences reveal numerous 
uncultured microorganisms in a natural community. Nature 345, 63-65.

Weiner, J.A., DeLorenzo, M.E., Fulton, M.H., 2004. Relationship between uptake capacity and differential toxicity of the herbicide atrazine in selected microalgal species. Aquat. Toxicol. 68, 121-128.

Widenfalk, A., Bertilsson, S., Sundh, I., Goedkoop, W., 2008. Effects of pesticides on community composition and activity of sediment microbes - responses at various levels of microbial community organization. Environ. Pollut. 152, 576-584.

Woodburn, A., 2000. Glyphosate: production, pricing and use worldwide. Pest Manag. Sci. 56, 309-312.

Yasuno, M., Asaka, A., Kono, Y., 1993. Effects of pyraclofos (an organophosphorus insecticide) on nutrient enriched ecosystems. Chemosphere 27, 1813-1824.

Yoshino, K., Nishigaki, K., Husimi, Y., 1991. Temperature sweep gel electrophoresis: a simple method to detect point mutations. Nucl. Acids Res. 19, 3153.

Yu, Y., Kong, F., Wang, M., Qian, L., Shi, X., 2007. Determination of short-term copper toxicity in a multispecies microalgal population using flow cytometry. Ecotox. Environ. Safe. 66, 49-56.

Zapata, M., Rodríguez, F., Garrido, J.L., 2000. Separation of chlorophylls and carotenoids from marine phytoplankton: a new HPLC method using a reversed phase C8 column and pyridine-containing mobile phases. Mar. Ecol. Prog. Ser. 195, 29-45. 
Table 1- Number of species and Shannon-Wiener index calculated from microscopic analyses of samples from the surrounding water (SW) and the microcosm experiment. 5 pooled samples for each analysis.

Table 2-Glyphosate ( $\mu \mathrm{g} \mathrm{L}^{-1}$ ) detected in microcosms and surrounding water on the first and last days of experiment. Detection limit: $0.05 \mu \mathrm{g} \mathrm{L}^{-1}$.

Figure 1-Scheme of the frame holding the microcosms.

Figure 2-Cytograms of side scatter and fluorescence of a seawater sample, showing the populations of Synechococcus, prasinophyte-like, and larger eukaryotes.

Figure 3-Chl a concentrations ( $\mu \mathrm{g} \mathrm{L}^{-1}$ ) in surrounding water on the first and last day of experiment (SW day 0, SW day 7), and in control microcosms on the last day (Control day 7).

Figure 4-Cellular concentrations of the Synechococcus, and total pico-eukaryote populations discriminated by flow cytometry analysis on surrounding water samples taken on the first and last day of experiment (SW day 0 and SW day 7), and in control microcosms on the last day (control day 7).

Figure 5-Relative abundances of the main phytoplankton groups identified by microscopy in surrounding water on the first and last day of experiment (SW day 0 and SW day 7), and in control microcosms on the last day of experiment (control day 7).

Figure 6-Chl a concentrations $\left(\mu \mathrm{g} \mathrm{L}^{-1}\right)$ in microcosms on the last day of experiment.

Figure 7a-TTGE profiles from 16S PCR products. C = Control; R1 = Roundup $1 \mu \mathrm{g} \mathrm{L}^{-1}$; R10 = Roundup $10 \mu \mathrm{g} \mathrm{L}^{-1}$; a,b,c,d = replicates.

Figure 7b-UPGMA cluster analysis of Dice similarity matrix calculated from 16S-TTGE banding patterns. $\mathrm{C}=$ Control; $\mathrm{R} 1=$ Roundup $1 \mu \mathrm{g} \mathrm{L}{ }^{-1}$; R10 = Roundup $10 \mu \mathrm{g} \mathrm{L}^{-1}$; a,b,c,d = replicates.

Figure 8-Cellular concentrations of the photosynthetic populations in microcosms on the last day of experiment, discriminated using flow cytometry.

Figure 9a-TTGE profiles of 18S PCR products. $\mathrm{C}=$ Control; R1 $=$ Roundup $1 \mu \mathrm{g} \mathrm{L}^{-1}$; R10 = Roundup $10 \mu \mathrm{g} \mathrm{L}^{-1}$; a,b,c,d = replicates.

Figure 9b-UPGMA cluster analysis of the Dice similarity matrix calculated from 18S-TTGE banding patterns. $\mathrm{C}=$ Control; R1 = Roundup $1 \mu \mathrm{g} \mathrm{L}^{-1}$; R10 = Roundup $10 \mu \mathrm{g} \mathrm{L}^{-1}$; a,b,c,d = replicates.

Figure 10-Cellular concentrations of the prasinophyte-like population in microcosms on the last day of experiment, discriminated using flow cytometry.

Figure 11- Relative abundances of the main phytoplankton groups identified by microscopy in microcosms on the last day of experiment. 
Figure 1

Figure 1

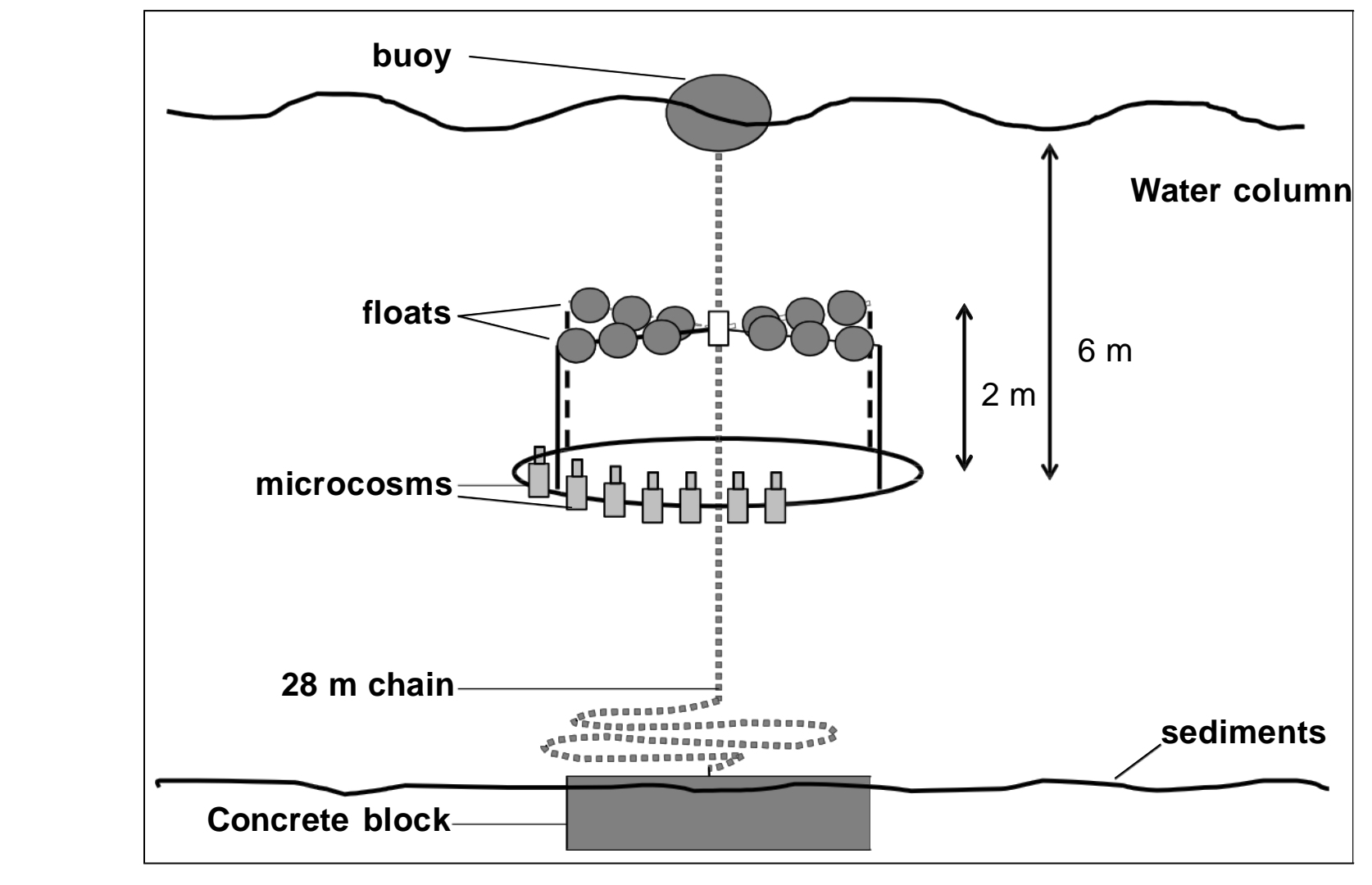


Figure 2
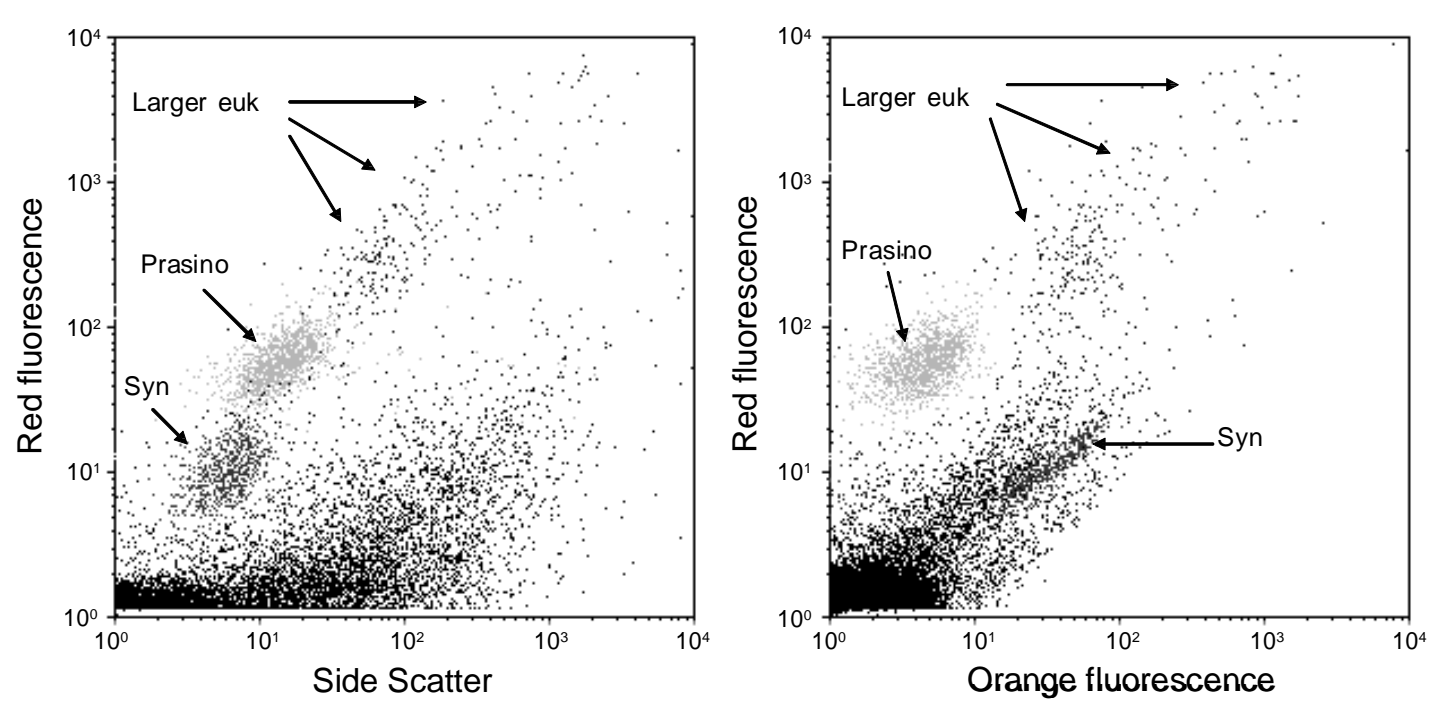

Figure 2 
Figure 3

Figure 3

$$
2,0-
$$

T1,5 -

올

들

䒿 1,0 -

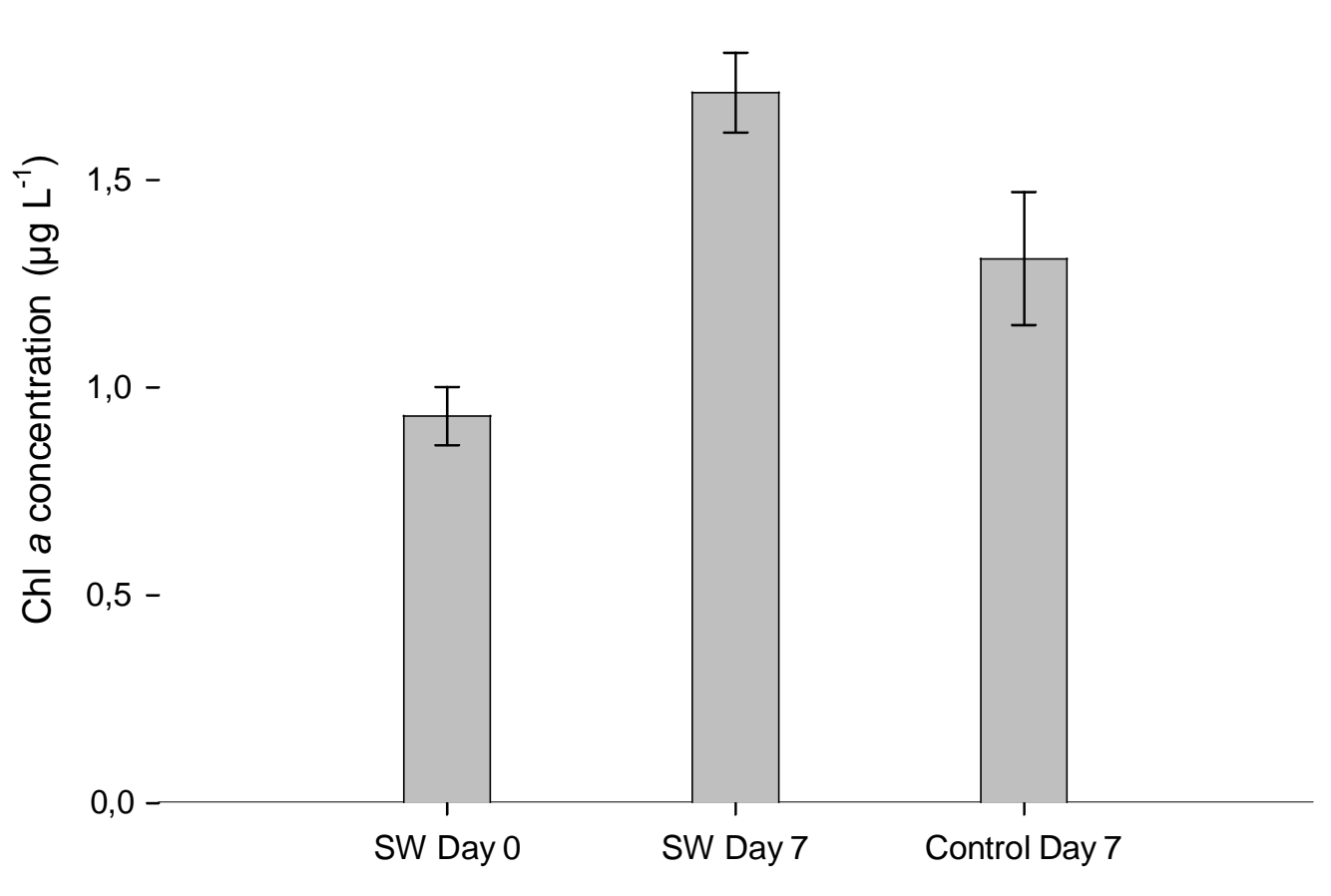

0,0

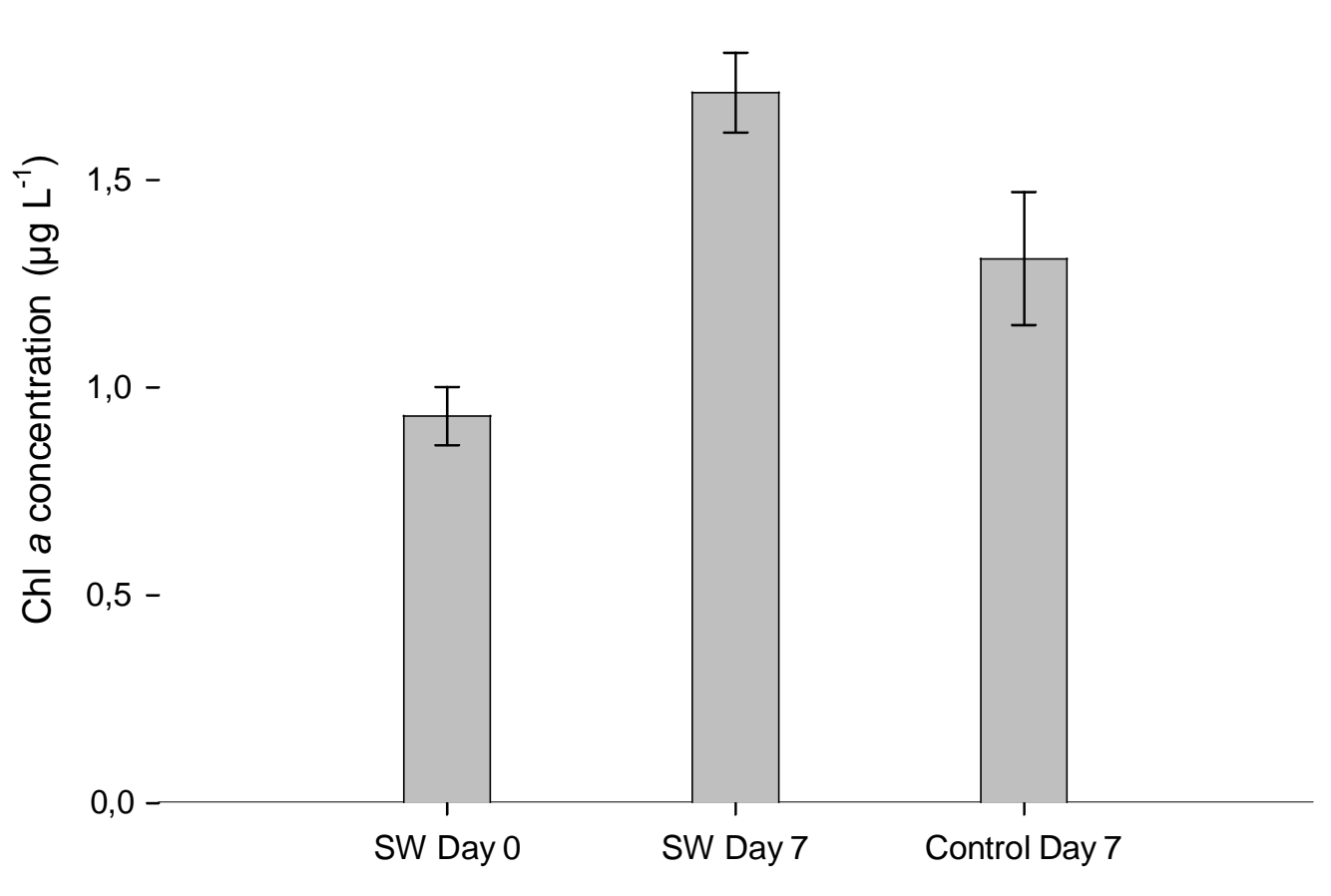


Figure 4

Figure 4

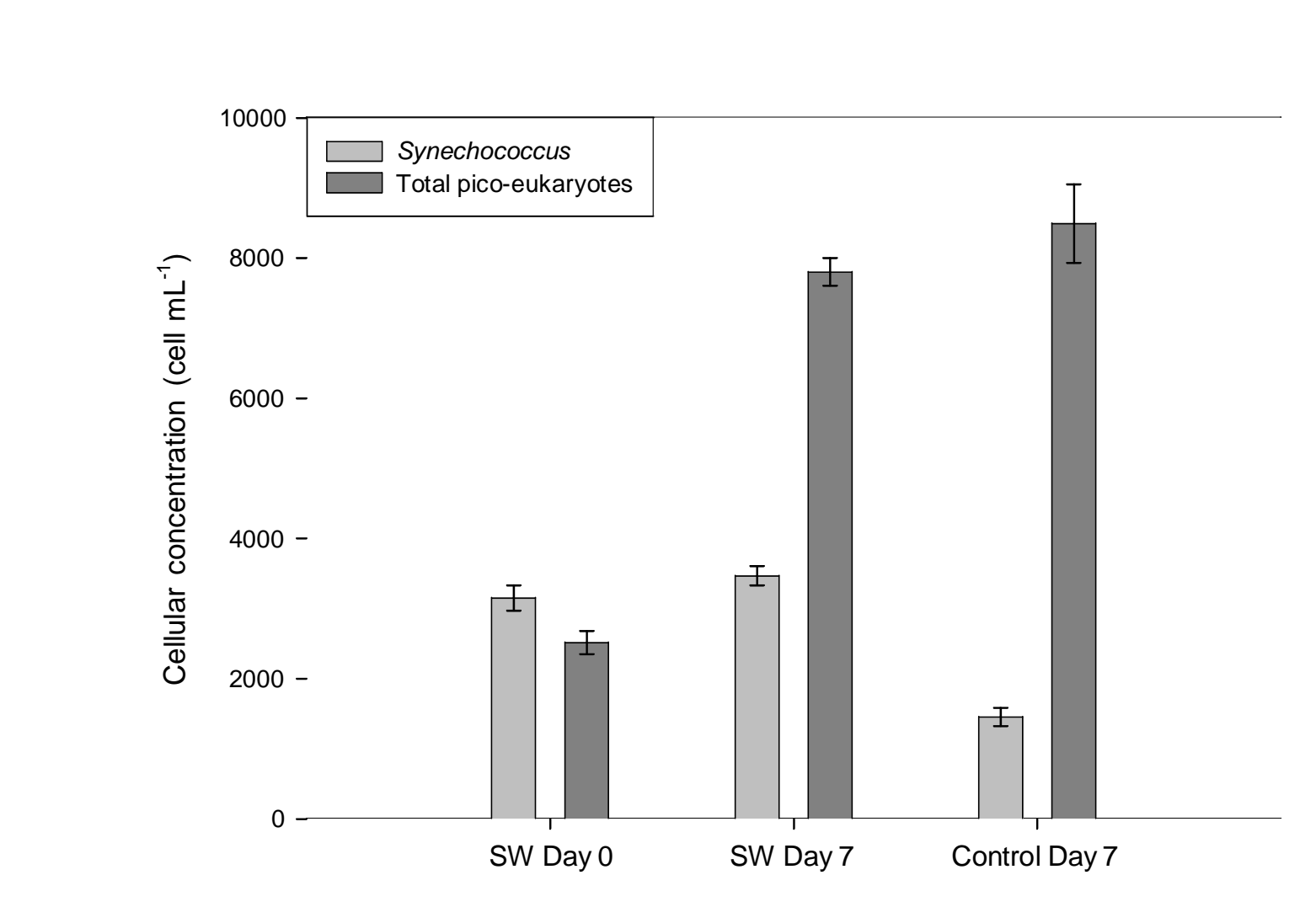

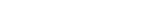

-

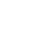

Figure 4 r

\section{Fure 4}

(1)
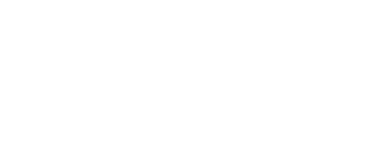

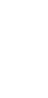


Figure 5

Figure 5
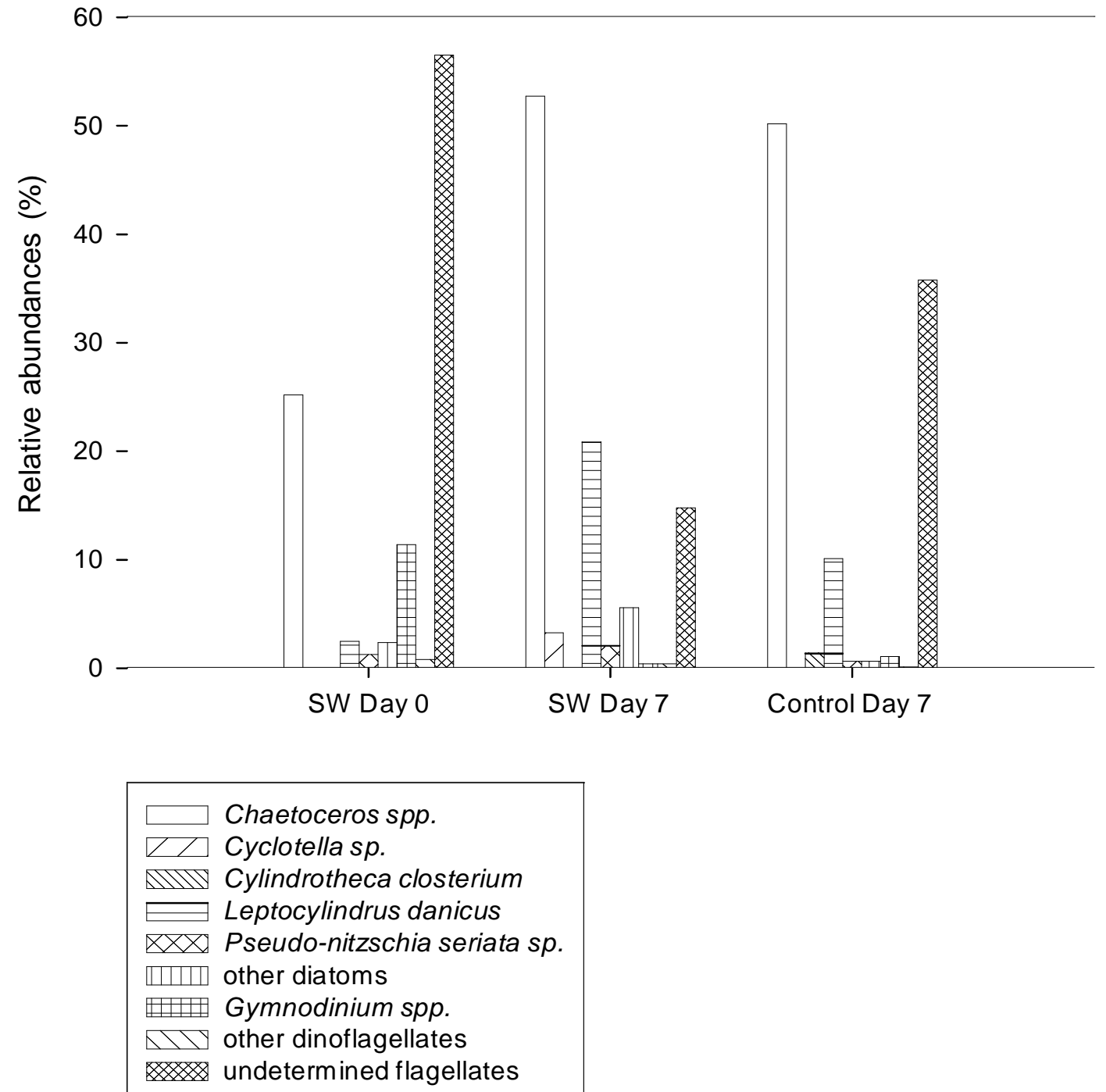
Figure 6

Figure 6

$$
2,0
$$
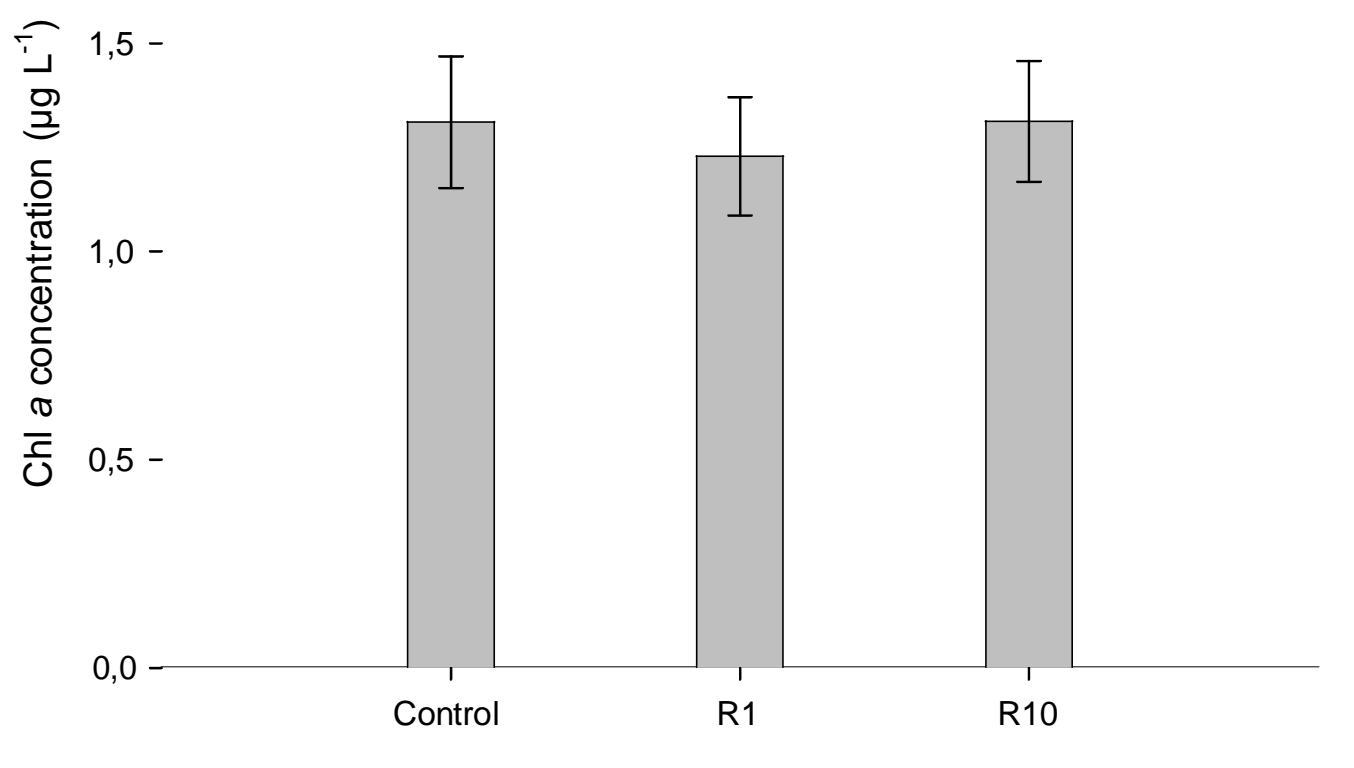

R1 R10 
Figure 7

Figure 7a

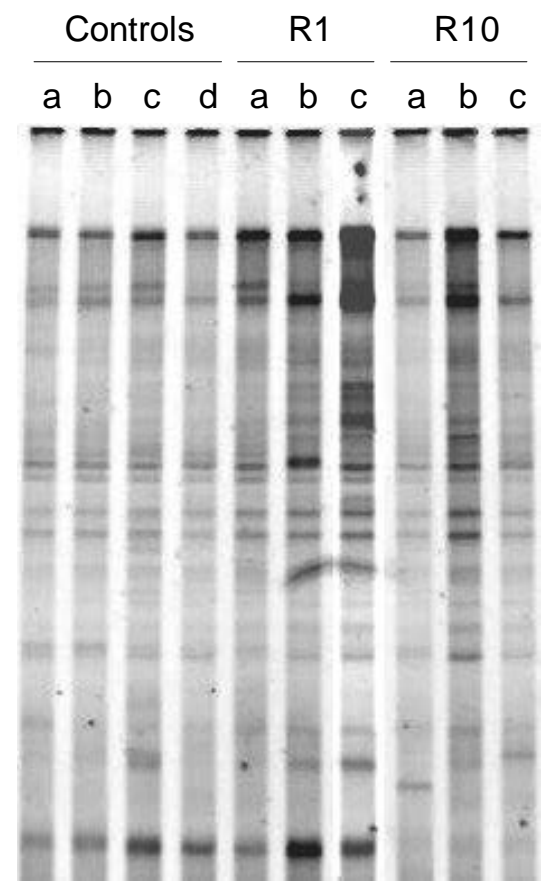

Figure $7 b$

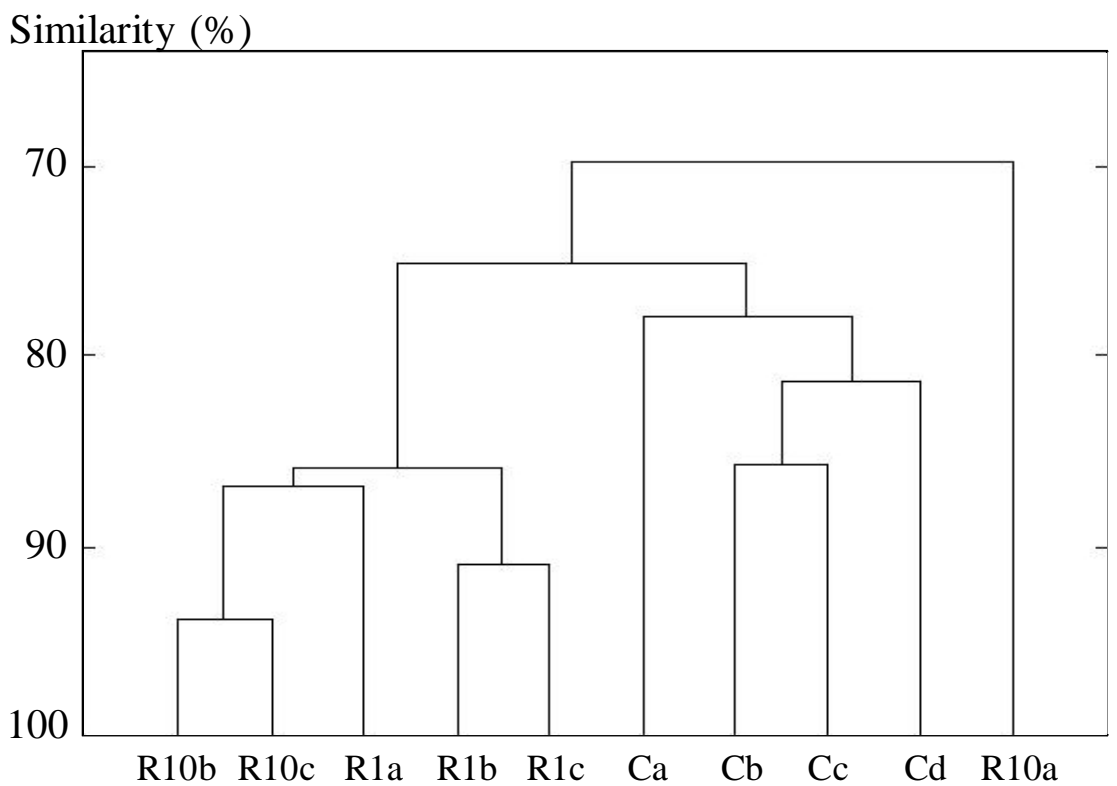


Figure 8

Figure 8

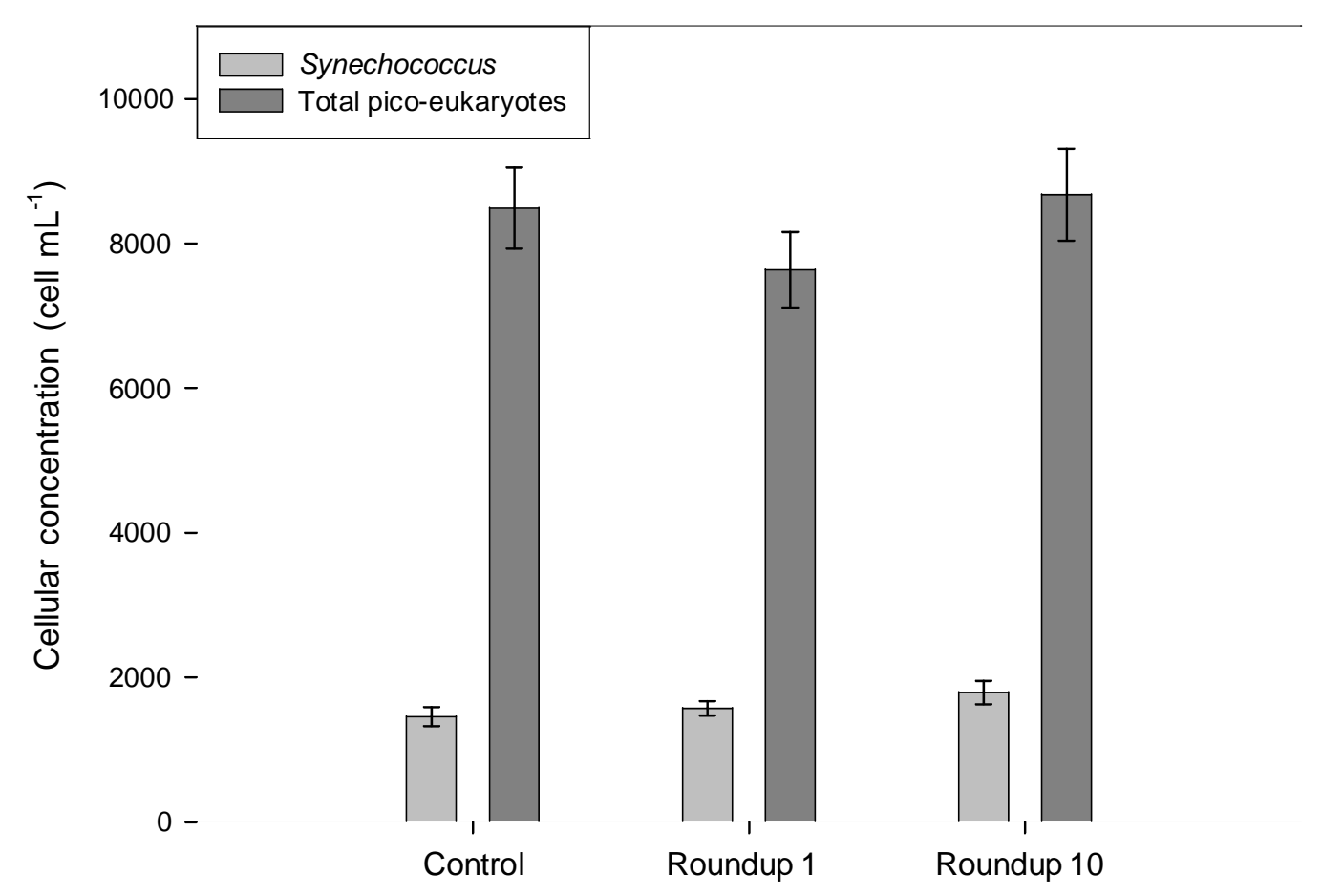


Figure 9

Figure 9a

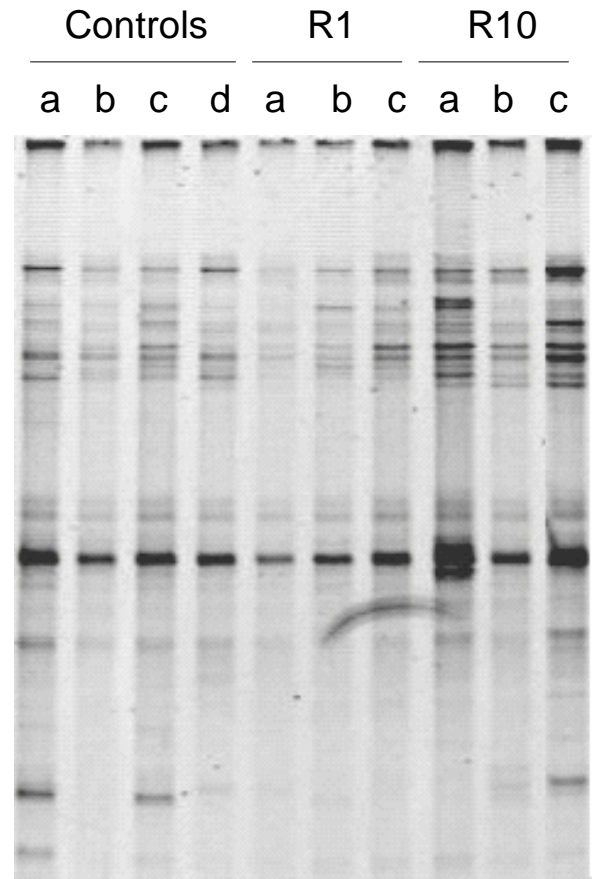

Figure 9b

Similarity (\%)

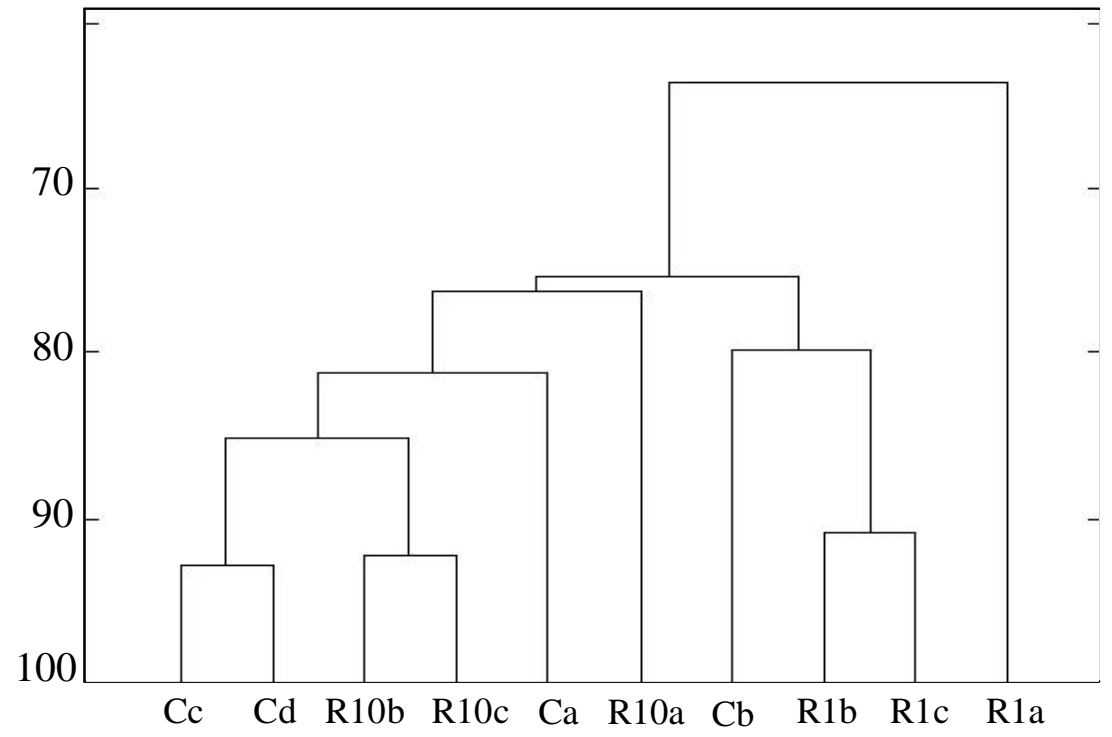


Figure 10
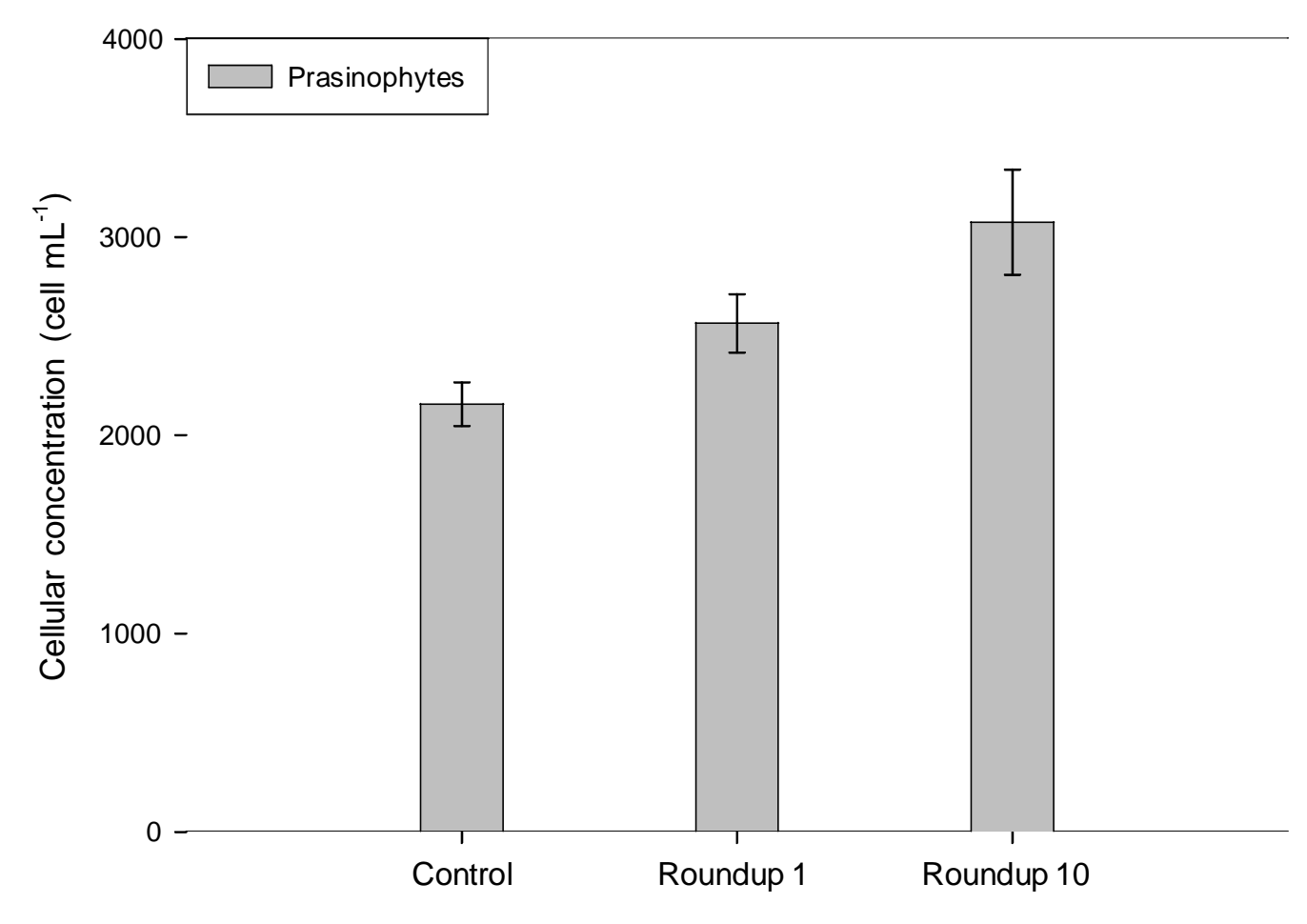

Figure 10 
Figure 11

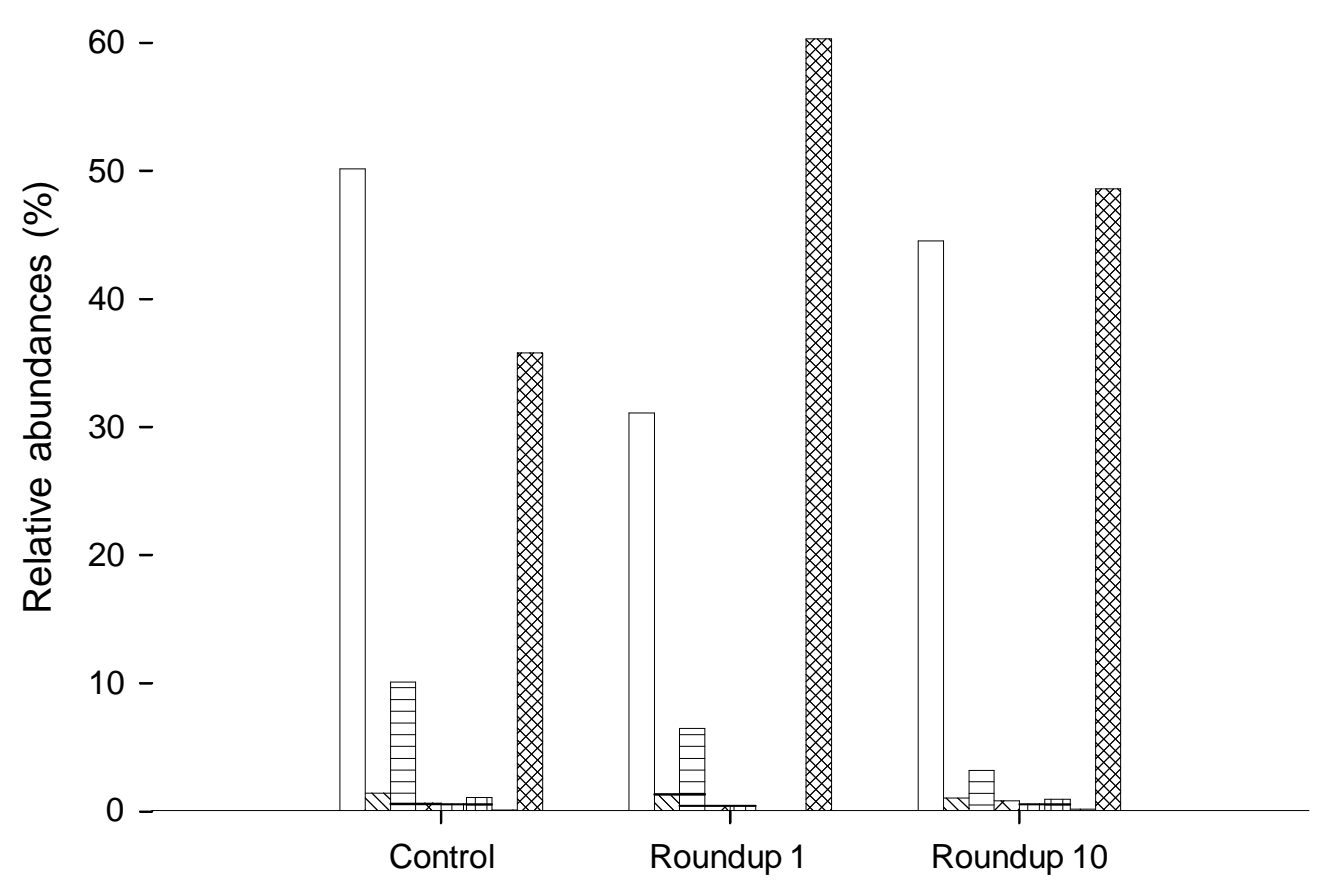

Chaetoceros spp.

AIV Cylindrotheca closterium

Leptocylindrus danicus

$\bowtie \times$ Pseudo-nitzschia seriata sp.

एणा] other diatoms

Gymnodinium spp.

$\triangle \backslash \nabla$ other dinoflagellates

undetermined flagellates 
Table 1

Table 1

\begin{tabular}{lccccc}
\hline & SW Day 0 & SW Day 7 & Control & Roundup $1 \mu \mathrm{L}^{-1}$ & ${\text { Roundup } 10 \mu \mathrm{L}^{-1}}^{-1}$ \\
\hline NUMBER OF SPECIES & 31 & 30 & 32 & 24 & 26 \\
\hline $\mathrm{H}^{\prime}$ & 2.12 & 2.29 & 1.99 & 1.59 & 1.87 \\
\hline
\end{tabular}


Table 2

Table 2

\begin{tabular}{ccccc}
\hline & Surrounding seawater & Control & Roundup 1 & Roundup 10 \\
\hline Day 0 & $<0.05$ & $<0.05$ & 0.11 & 3.56 \\
Day 7 & $<0.05$ & $<0.05$ & 0.13 & 3.08 \\
\hline
\end{tabular}

